\title{
Employment Consequences of Restrictive Permanent Contracts: Evidence from Spanish Labor Market Reforms
}

\author{
Adriana Kugler \\ Universitat Pompeu Fabra, CEPR and IZA \\ Juan F. Jimeno \\ Universidad de Alcalá, FEDEA, CEPR and IZA \\ Virginia Hernanz \\ Universidad de Alcalá
}

November, 2002

\footnotetext{
* We are grateful to John Abowd, Joe Altonji, Josh Angrist, Manolo Arellano, Samuel Bentolila, Richard Blundell, Olympia Bover, Raquel Carrasco, Antonio Ciccone, Juanjo Dolado, Richard Freeman, Walter Garcia-Fontes, José Garcia Montalvo, David Green, Christian Haefke, Dan Hamermesh, Jenny Hunt, Larry Katz, Angel López, Steve Machin, Steve Pischke, Javier Ruiz-Castillo, Miquel Urquiola, and to seminar participants at the 2002 NBER Summer Institute, the 2002 SOLE meeting, the 2002 ESPE meeting, Universidad Carlos III, and Universitat Pompeu Fabra for comments. We would also like to thank Mario Izquierdo and Climent Quintana i Domeque for able research assistance. Adriana Kugler thanks the Spanish Ministry of Science and Technology through Grant No. SEC-2000-1034 for financial support. Address for correspondence: Adriana Kugler, Department of Economics, Universitat Pompeu Fabra, Ramón Trías Fargas, 25-27, 08005 Barcelona, Spain. E-mail: adriana.kugler@econ.upf.es.
} 


\begin{abstract}
Temporary employment contracts allowing unrestricted dismissals were introduced in Spain in 1984 and quickly came to account for most new jobs. As a result, temporary employment increased from around $10 \%$ in the mid-eighties to more than $30 \%$ in the early nineties. In 1997, however, the Spanish government attempted to reduce the incidence of temporary employment by reducing payroll taxes and dismissal costs for permanent contracts. In this paper, we use individual data from the Spanish Labor Force Survey to estimate the effects of reduced payroll taxes and dismissal costs on the distribution of employment and worker flows. We exploit the fact that recent reforms apply only to certain demographic groups to set up a natural experiment research design that can be used to study the effects of contract regulations. Our results show that the reduction of payroll taxes and dismissal costs increased the employment of young workers on permanent contracts, although the effects for young women are not always significant. Results for older workers show insignificant effects. The results suggest a moderately elastic response of permanent employment to non-wage labor costs for young men. We also find positive effects on the transitions from unemployment and temporary employment into permanent employment for young and older workers, although the effects for older workers are not always significant. On the other hand, transitions from permanent employment to non-employment increased only for older men, suggesting that the reform had little effect on dismissals.
\end{abstract}

Keywords: Temporary Employment, Dismissal Costs, Payroll Taxes, European Unemployment.

JEL Codes: J23, J32, J38, J63, J65. 


\section{Introduction}

The European unemployment crisis has motivated extensive debate about the role of labor market institutions in exacerbating unemployment. Concern with possible adverse effects of inflexibility has stimulated research and calls for reform. While a role for institutions is superficially appealing, the evidence for their importance has been mixed (see, e.g., Nickell and Layard (1999) for a recent survey) and the interpretation of results remains controversial. One reason the causal effect of institutional changes has been difficult to establish is the lack of sharp changes or reforms that can be used for measurement. Most institutional changes in the European context have been either gradual or so widespread that it is difficult to identify control groups that can be used to establish a non-reform baseline for comparison.

A second important feature of most reforms to date, and consequently of efforts to evaluate these reforms, is that they are "reforms at the margin" which fail to introduce a fundamental liberalization. In fact, some reforms may simply add further distortions. The most important example of this is the introduction of temporary contracts, a common liberalization strategy in Western Europe. Rather than reducing dismissal costs for permanent contracts, these reforms introduced temporary employment contracts that are not subject to dismissal costs. Allowing the use of temporary contracts without dismissal costs is, however, not equivalent to reducing dismissal costs on permanent contracts. The introduction of this new type of contract may increase the wages of permanent workers and have undesirable consequences for output, employment, and segmentation of the labor market.

\footnotetext{
${ }^{1}$ See, for example, Blanchard and Landier (2002); Dolado, Garcia-Serrano, and Jimeno (2002), and Bertola and Ichino (1995).
} 
In this paper, we asses the impact of a recent reform in the Spanish labor market. A study of the recent Spanish experience is especially compelling because, in contrast with the majority of Continental reforms, Spain's 1997 Reform bill, extended in 2001, marks a sharp change for some groups (i.e., young workers, older workers, the longterm unemployed, women under-represented in their occupations, and disabled workers), while leaving other groups unaffected. This presents an opportunity to set up a treatment-control design that may provide more reliable estimates of reform effects than past efforts. A second unique feature of recent Spanish reforms is that, unlike previous "reforms at the margin," they led to sharp reductions in payroll taxes and dismissal costs for permanent contracts. Consequently, these reforms may provide a better estimate of the elasticity of permanent employment with respect to non-wage labor costs.

The theoretical section of the paper presents a model with temporary and permanent contracts to illustrate the impact of reduced payroll taxes and dismissal costs on employment. The model is similar to Blanchard and Landier (2000), but it endogenizes dismissals and introduces payroll taxes. In our model, a reduction in dismissal costs for permanent contracts increases conversions of temporary into permanent employment, but it also increases dismissals of permanent workers so the net effect on permanent employment is ambiguous. By contrast, a reduction in payroll taxes increases conversions but leaves dismissals unchanged, so its net effect is to increase permanent employment.

The empirical analysis examines the impact of the 1997 reform on employment and worker flows using data from the Spanish labor force survey from the second quarter of 1987 to the fourth quarter of 2000. The Spanish LFS collects basic individual 
and family information, as well as labor market information, including type of employment contract. In addition, the LFS has a rotating panel structure that allows us to estimate quarterly transition probabilities.

Our results suggest the reform increased permanent employment probabilities for young workers, although the effects for young women are not always significant. The results for young men are robust to controls for common macro shocks for all age groups, for sector- and province-specific trends, and for age-specific cyclical effects. Results for older workers show smaller and insignificant effects. The estimates also show increased quarterly transition probabilities from non-employment to permanent employment for young and older men, although the results for older men are not always significant, and from temporary to permanent employment for young men and women during the reform years. On the other hand, transition probabilities from permanent employment to non-employment increased for older men, accounting for weak net employment effects for this group. An implication of these findings is that costly permanent contracts and high payroll taxes inhibit employment growth in Spain. The results also suggest that reducing the costs of permanent employment may be of special value for younger workers.

The paper is organized as follows. Section II describes the institutional framework and the Spanish labor market reforms. Section III presents a theoretical analysis of reductions in payroll taxes and dismissal costs for permanent contracts introduced by recent reforms. Section IV explains the natural experiment research design used to evaluate the impact of the 1997 reform. Section V describes the data and presents estimates of the effects of the reform on employment levels, accessions, conversions, and separations. We conclude in Section VI. 


\section{The Spanish Labor Market Reforms}

The Spanish labor market has been marked by substantial changes in employment protection legislation over the last two decades. Following the transition to democracy in 1978, Spain introduced labor legislation which maintained many restrictions on dismissals first put into practice during the Franco years. This legislation established that firms could dismiss workers for "personal reasons," in which case the firm had to prove the worker's incompetence or absenteeism; and "economic reasons," in which case the firm had to prove its need to reduce employment due to technological, organizational, or productive causes. Dismissals justified by "economic reasons" required advance notice.

Workers dismissed for "personal reasons" could appeal to labor courts. The severance payment awarded depended on whether judges ruled the dismissal as "fair" or "unfair." A dismissal was ruled as "fair" if the employer was able to prove the worker's incompetence or absenteeism and "unfair" otherwise. In case of fair dismissals, firms had to pay 20 days out of the salary per year of seniority, with a maximum of 12 months. In the case of unfair dismissals, firms had to pay 45 days per year of seniority out of the salary, with a maximum of 42 months. Severance payments for "economic reasons" were the same as for fair dismissals under "personal reasons." In practice, this legislation turned out to be very stringent because judges ruled dismissals as unfair in the majority of cases. Moreover, approval for dismissals under "economic reasons" was often granted only when there was an agreement between employers and workers, which was achieved in most cases by raising severance payments above the legally established amounts. 
The Spanish government introduced the first reform designed to reduce dismissal costs in 1984. Since an across-the-board reduction of dismissal costs was politically impossible, the reform liberalized the use of temporary contracts. Temporary contracts required lower severance payments than permanent contracts when the contract terminated at term. In particular, temporary workers were entitled to 12 days per year of seniority based on the salary and could not be appealed in labor courts.

As a result of the 1984 reform, the proportion of employees under temporary contracts increased from $10 \%$ during the 1980 's to over $30 \%$ in the early 1990 's. Between 1985 and 1994, over 95\% of all new hires were employed through temporary contracts and the conversion rate from temporary to permanent contracts was only around $10 \%$. The main concern with the liberalization of temporary contracts after 1984 was that it generated segmentation between unstable low-paying jobs and stable high-paying jobs, without appearing to reduce unemployment.

Shifting direction in light of these concerns, in 1994 new regulations limited the use of temporary employment contracts to seasonal jobs. ${ }^{3}$ In practice, however, employers continued to hire workers under temporary contracts for all types of jobs and not just for seasonal jobs. In addition, the 1994 reform slightly relaxed dismissal conditions for permanent contracts. In particular, the definition of fair dismissals was widened by including additional "economic reasons" for dismissals. In practice, approval for dismissals under "economic reasons" continued to be granted mainly when there was an agreement between employers and workers and labor courts continued to

\footnotetext{
${ }^{2}$ See Güell-Rottlan and Petrongolo (2000).

${ }^{3}$ In the case of workers over 45 years of age, temporary contracts could be continued to be used for all types of jobs and not only for seasonal jobs until 1995. After 1995, however, the use of temporary contracts for the over 45 age group, as for the rest of workers, was limited to seasonal jobs.
} 
rule most dismissals as unfair, so that dismissal costs on permanent contracts did not change much.

The perceived ineffectiveness of the 1994 reform led to a new reform in 1997, which was eventually extended in 2001. As with the 1994 reform, the goal of the 1997 and 2001 reforms was to reduce the use of temporary contracts. However, rather than trying to limit the use of temporary contracts by further possibly ineffective regulation, the new reform increased the incentives for firms to hire workers in certain population groups using permanent contracts. In particular, the 1997 reform reduced dismissal costs for unfair dismissals by about $25 \%$ and payroll taxes between $40 \%$ and $90 \%$ for newly signed permanent contracts and for conversions of temporary into permanent contracts after the second quarter of 1997 for workers under 30 years of age, over 45 years of age, the long-term unemployed, women under-represented in their occupations, and disabled workers.

Key provisions of the 1997 reform are summarized in Table 1. Severance payments for unfair dismissals of newly signed contracts of workers in affected groups were reduced from 45 to 33 days out of the salary per year of seniority and the maximum was reduced from 42 to 24 months out of the salary. In addition, given the high payroll tax rate in Spain (i.e., $28.3 \%$ of the salary), the reform reduced payroll taxes between $40 \%$ and $90 \%$ for workers in these population groups hired under permanent contracts. ${ }^{4}$ Table 1 shows that payroll tax reductions went from $40 \%$ for workers under 30 years of age and for long-term unemployed, to between $70 \%$ and $90 \%$

\footnotetext{
${ }^{4}$ Payroll taxes are generally high in all Continental Europe (with Denmark being an exception) and have often being pointed as an explanation for high unemployment in Europe. Laroque and Salanie (2002), and Kramarz and Philippon (1999) study the consequences of high payroll taxes in France.
} 
for disabled workers. Table 1 shows that in some cases payroll taxes were also reduced after the second year of employment.

The research value of the 1997 reform is partly due to the fact that the new regulations affected different groups of workers differently. In particular, the 1997 reform changed payroll taxes and dismissal costs over time differently for different population groups: younger and older workers, the long-term unemployed, women under-represented in their occupations, and disabled workers. Our estimation strategy exploits the temporal as well as the cross-section variation to evaluate the impact of the reduction in payroll taxes and dismissal costs on employment levels and flows.

The 1997 reform led to a sharp and sustained increase in the number of permanent contracts for workers in some affected groups. This can be seen in Figures 1 and 2, which plot the total number of newly signed permanent contracts and conversions of temporary into permanent contracts for men and women, respectively. The figures show that the number of newly signed permanent contracts increased sharply for young workers and older men, and to a lesser extent for older women, after the second quarter of 1997, but remained roughly constant for the long-term unemployed and disabled workers. On the other hand, the number of regular permanent contracts (i.e., contracts not subject to reductions in payroll taxes and dismissal costs) initially decreased in 1997 and then increased but at a lower rate than for younger workers. The figures also show a marked rise in the number of conversions of temporary into permanent contracts after the second quarter of 1997 for both men and women. The sharp rise in conversions and new permanent contracts for young and

\footnotetext{
${ }^{5}$ The 2001 reform which became effective in January 2001 essentially extended the 1997 reform, but applied the lower subsidies for contracts signed in 1999 mentioned in Table 1.
} 
older workers after the second quarter of 1997 suggests the reform affected these groups of workers.

\section{Theoretical Consequences of the Reform}

This model illustrates the effects of reductions in payroll taxes and dismissal costs for permanent contracts, such as those introduced by the 1997 reform, when there are both temporary and permanent contracts in the economy. The model is similar to Blanchard and Landier's (2002) model but endogenizes dismissals of permanent workers and introduces payroll taxes to evaluate the impact of the reform.

Firms have a discount factor $r$, and they create and fill vacancies using temporary and permanent contracts. There is a cost $\mathrm{K}$ from creating a vacancy, which can be filled instantaneously by hiring workers from the pool of the unemployed (i.e., the matching technology is such that there are "workers waiting at the gate").

All jobs start with temporary contracts, which have productivity $\varepsilon_{0}$. The productivity of permanent jobs at a point in time, $\varepsilon$, is the realization of matchidiosyncratic productivity shocks, $\varepsilon^{\prime}$, drawn from a distribution $G$ with support $\left[\varepsilon_{0}, \varepsilon_{\mathrm{m}}\right]$. Both temporary and permanent jobs are subject to productivity shocks with instantaneous probability $\lambda$, where the new match-idiosyncratic productivity is drawn from the distribution G. Temporary jobs hit by shocks are either terminated or converted into permanent jobs, while permanent jobs hit by shocks are either terminated or continued. While temporary jobs are not subject to dismissal costs, permanent jobs are subject to dismissal costs, F, which are assumed to be pure waste. Both temporary and permanent jobs are subject to payroll taxes. Payroll taxes for temporary and permanent jobs are a fraction $\mathrm{s}_{\mathrm{T}}$ and $\mathrm{s}_{\mathrm{P}}$ of wages $\mathrm{w}_{\mathrm{T}}$ and $\mathrm{w}_{\mathrm{P}}$, respectively. The values of 
temporary and permanent jobs are $\mathrm{J}_{\mathrm{T}}\left(\varepsilon_{\mathrm{o}}\right)$ and $\mathrm{J}_{\mathrm{P}}(\varepsilon)$ and given by the following Bellman equations:

$$
\begin{gathered}
\mathrm{rJ}_{\mathrm{T}}\left(\varepsilon_{\mathrm{o}}\right)=\varepsilon_{\mathrm{o}}-\left(1+\mathrm{s}_{\mathrm{T}}\right) \mathrm{w}_{\mathrm{T}}\left(\varepsilon_{\mathrm{o}}\right)+\lambda \mathrm{E}\left(\mathrm{J}_{\mathrm{P}}\left(\varepsilon^{\prime}\right)-\mathrm{J}_{\mathrm{T}}\left(\varepsilon_{\mathrm{o}}\right) \mid \varepsilon^{\prime} \geq \underline{\varepsilon}\right), \\
\mathrm{rJ}_{\mathrm{P}}(\varepsilon)=\varepsilon-\left(1+\mathrm{S}_{\mathrm{P}}\right) \mathrm{w}_{\mathrm{P}}(\varepsilon)+\lambda \mathrm{E}\left(\mathrm{J}_{\mathrm{P}}\left(\varepsilon^{\prime}\right)-\mathrm{J}_{\mathrm{P}}(\varepsilon) \mid \varepsilon^{\prime} \geq \bar{\varepsilon}\right)+\lambda\left(\mathrm{J}_{\mathrm{T}}\left(\varepsilon_{\mathrm{o}}\right)-\mathrm{J}_{\mathrm{P}}(\varepsilon)-\mathrm{F}\right) \mathrm{G}(\bar{\varepsilon}),
\end{gathered}
$$

where $\underline{\varepsilon}$ is the threshold match-idiosyncratic productivity at which firms are indifferent between dismissing and converting temporary into permanent jobs, and $\bar{\varepsilon}$ is the threshold match-idiosyncratic productivity at which firms are indifferent between dismissing and retaining workers.

The labor force is normalized to 1. Individuals are infinitely lived, risk-neutral and have a discount factor $\mathrm{r}$. Workers employed in temporary and permanent jobs receive wages $\mathrm{w}_{\mathrm{T}}$ and $\mathrm{w}_{\mathrm{P}}$ and a fraction of benefits $\mathrm{b}$ financed by firms' payroll contributions for temporary and permanent jobs, $\mathrm{s}_{\mathrm{T}} \mathrm{W}_{\mathrm{T}}$ and $\mathrm{s}_{\mathrm{P}} \mathrm{W}_{\mathrm{P}}$ (where $\mathrm{b}=1$ implies a perfect link between benefits and contributions). Workers dismissed from permanent jobs and whose temporary jobs end enter unemployment. Unemployed workers have zero utility and they must start with temporary jobs before moving up to permanent jobs. The arrival rate of temporary jobs is $\varphi=h / u$, where $h$ are total hires and $u$ unemployment. The value to a worker of being employed in a temporary job with productivity $\varepsilon_{0}$, of being employed in a permanent job with productivity $\varepsilon$, and of being unemployed are $\mathrm{W}_{\mathrm{T}}\left(\varepsilon_{\mathrm{o}}\right), \mathrm{W}_{\mathrm{P}}(\varepsilon)$, and $\mathrm{U}$, and are given by the following Bellman equations:

$$
\begin{gathered}
\operatorname{rW}_{\mathrm{T}}\left(\varepsilon_{\mathrm{o}}\right)=\left(1+\mathrm{bs}_{\mathrm{T}}\right) \mathrm{W}_{\mathrm{T}}\left(\varepsilon_{\mathrm{o}}\right)+\lambda \mathrm{E}\left(\mathrm{W}_{\mathrm{P}}\left(\varepsilon^{\prime}\right)-\mathrm{W}_{\mathrm{T}}\left(\varepsilon_{\mathrm{o}}\right) \mid \varepsilon^{\prime} \geq \underline{\varepsilon}\right)+\lambda\left(\mathrm{U}-\mathrm{W}_{\mathrm{T}}\left(\varepsilon_{\mathrm{o}}\right)\right) \mathrm{G}(\underline{\varepsilon}), \\
\mathrm{rW}_{\mathrm{P}}(\varepsilon)=\left(1+\mathrm{bs} \mathrm{S}_{\mathrm{P}}(\varepsilon)+\lambda \mathrm{E}\left(\mathrm{W}_{\mathrm{P}}\left(\varepsilon^{\prime}\right)-\mathrm{W}_{\mathrm{P}}(\varepsilon) \mid \varepsilon^{\prime} \geq \bar{\varepsilon}\right)+\lambda\left(\mathrm{U}-\mathrm{W}_{\mathrm{P}}(\varepsilon)\right) \mathrm{G}(\bar{\varepsilon}),\right. \\
\mathrm{rU}=\varphi\left(\mathrm{W}_{\mathrm{T}}\left(\varepsilon_{\mathrm{o}}\right)-\mathrm{U}\right) .
\end{gathered}
$$

Free entry implies that the number of vacancies is determined by zero net profit, 
$\mathrm{J}_{\mathrm{T}}\left(\varepsilon_{\mathrm{o}}\right)=\mathrm{K}$. Moreover, since the value of permanent jobs increases with the matchidiosyncratic productivity, $\varepsilon$, the conversion threshold, $\underline{\varepsilon}$, above which temporary jobs are converted into permanent jobs and the dismissal threshold, $\bar{\varepsilon}$, below which permanent workers are dismissed are given by the following equations:

$$
\begin{aligned}
& \mathrm{J}_{\mathrm{P}}(\underline{\varepsilon})=\mathrm{J}_{\mathrm{T}}\left(\varepsilon_{\mathrm{o}}\right)=\mathrm{K} \\
& \mathrm{J}_{\mathrm{P}}(\bar{\varepsilon})=\mathrm{J}_{\mathrm{T}}\left(\varepsilon_{\mathrm{o}}\right)-\mathrm{F}
\end{aligned}
$$

Wages in both types of jobs are set by symmetric Nash bargaining, with continuous renegotiation. The Nash-bargaining conditions for temporary and permanent jobs are:

$$
\begin{gathered}
\mathrm{J}_{\mathrm{T}}\left(\varepsilon_{\mathrm{o}}\right)-\mathrm{K}=\mathrm{W}_{\mathrm{T}}\left(\varepsilon_{\mathrm{o}}\right)-\mathrm{U}, \\
\mathrm{J}_{\mathrm{P}}(\varepsilon)-\mathrm{J}_{\mathrm{T}}\left(\varepsilon_{\mathrm{o}}\right)+\mathrm{F}=\mathrm{W}_{\mathrm{P}}(\varepsilon)-\mathrm{U}
\end{gathered}
$$

Substituting the free-entry condition into equation (3) implies that the value of being employed in a temporary job is equal to the value of being unemployed, $\mathrm{W}_{\mathrm{T}}\left(\varepsilon_{\mathrm{o}}\right)=\mathrm{U}$, and both are equal to zero. Integrating equation (4) over $\underline{\varepsilon}$ and $\varepsilon_{\mathrm{m}}$, yields $\mathrm{E}\left(\mathrm{J}_{\mathrm{P}}\left(\varepsilon^{\prime}\right)-\mathrm{W}_{\mathrm{P}}\left(\varepsilon^{\prime}\right) \mid \varepsilon^{\prime} \geq \underline{\varepsilon}\right)=(\mathrm{K}-\mathrm{F})(1-\mathrm{G}(\underline{\varepsilon}))$. Using this together with the fact that the value of being unemployed is zero and with the Bellman equations for a temporary job yields the temporary wage,

$$
\mathrm{w}_{\mathrm{T}}\left(\varepsilon_{\mathrm{o}}\right)=\left[\varepsilon_{\mathrm{o}}-\mathrm{rK}-\lambda \mathrm{F}(1-\mathrm{G}(\underline{\varepsilon}))\right] /\left[2+(1+\mathrm{b}) \mathrm{s}_{\mathrm{T}}\right] .
$$

Similarly, integrating (4) over $\underline{\varepsilon}$ and $\varepsilon_{\mathrm{m}}$, yields $\mathrm{E}\left(\mathrm{J}_{\mathrm{P}}\left(\varepsilon^{\prime}\right)-\mathrm{W}_{\mathrm{P}}\left(\varepsilon^{\prime}\right) \mid \varepsilon^{\prime} \geq \bar{\varepsilon}\right)=$ $(\mathrm{K}-\mathrm{F})(1-\mathrm{G}(\bar{\varepsilon}))$. This together with the fact that the value of being unemployed is zero and with the Bellman equations for a permanent job yields the permanent wage,

$$
\mathrm{W}_{\mathrm{P}}(\varepsilon)=[\varepsilon-\mathrm{r}(\mathrm{K}-\mathrm{F})] /\left[2+(1+\mathrm{b}) \mathrm{S}_{\mathrm{P}}\right] .
$$


There is a unique wage for temporary jobs, since they all have the same level of productivity, $\varepsilon_{0}$. On the other hand, wages in permanent jobs depend on the matchidiosyncratic productivity, $\varepsilon$.

Substituting wages and the free-entry condition into the value of a permanent job, and evaluating at the conversion and dismissal thresholds yields two equations which define the conversion and dismissal thresholds implicitly,

$$
\begin{gathered}
(\mathrm{r}+\lambda) \mathrm{K}=\left\{\left[\left(1+\mathrm{bs}_{\mathrm{P}}\right) \underline{\varepsilon}+\mathrm{r}(\mathrm{K}-\mathrm{F})\right] /\left[2+(1+\mathrm{b}) \mathrm{s}_{\mathrm{P}}\right]\right\}+\lambda \mathrm{E}\left(\mathrm{J}_{\mathrm{P}}\left(\varepsilon^{\prime}\right) \mid \varepsilon^{\prime} \geq \bar{\varepsilon}\right)+\lambda(\mathrm{K}-\mathrm{F}) \mathrm{G}(\bar{\varepsilon}) \\
(\mathrm{r}+\lambda)(\mathrm{K}-\mathrm{F})=\left\{\left[\left(1+\mathrm{bs}_{\mathrm{P}}\right) \bar{\varepsilon}+\mathrm{r}(\mathrm{K}-\mathrm{F})\right] /\left[2+(1+\mathrm{b}) \mathrm{s}_{\mathrm{P}}\right]\right\}+\lambda \mathrm{E}\left(\mathrm{J}_{\mathrm{P}}\left(\varepsilon^{\prime}\right) \mid \varepsilon^{\prime} \geq \bar{\varepsilon}\right)+\lambda(\mathrm{K}-\mathrm{F}) \mathrm{G}(\bar{\varepsilon})
\end{gathered}
$$

Subtracting (6) from (5) yields

$$
\underline{\varepsilon}-\bar{\varepsilon}=\left[2+(1+\mathrm{b}) \mathrm{s}_{\mathrm{P}}\right](\mathrm{r}+\lambda) \mathrm{F} /\left[1+\mathrm{bs}_{\mathrm{P}}\right] .
$$

Substituting the permanent wage into the value of permanent job, and then integrating by parts and using the threshold conditions (1) and (2), yields the individual thresholds,

$$
\begin{gathered}
\bar{\varepsilon}=(\mathrm{r}+\lambda)(\mathrm{K}-\mathrm{F})-\lambda \varepsilon_{\mathrm{m}} / \mathrm{r}+\lambda\left(\mathrm{G}\left(\varepsilon_{\mathrm{m}}\right)-\mathrm{G}(\bar{\varepsilon})\right) / \mathrm{r} \\
\underline{\varepsilon}=(\mathrm{r}+\lambda) \mathrm{K}-\lambda \varepsilon_{\mathrm{m}} / \mathrm{r}+\lambda\left(\mathrm{G}\left(\varepsilon_{\mathrm{m}}\right)-\mathrm{G}(\bar{\varepsilon})\right) / \mathrm{r}+(\mathrm{r}+\lambda)\left(1+\mathrm{s}_{\mathrm{P}}\right) \mathrm{F} /\left(1+\mathrm{bs}_{\mathrm{P}}\right),
\end{gathered}
$$

Comparative statics on these thresholds show that a reduction in dismissal costs reduces the difference between the conversion and dismissal thresholds both because the conversion threshold falls and because the dismissal threshold increases. A reduction in payroll taxes for permanent jobs also reduces the difference between the conversion and dismissal thresholds as long as the link between benefits and contributions is not perfect. In this case, however, only the conversion threshold falls.

Given the values of the two productivity thresholds, we can derive the steadystate values of unemployment, temporary employment and permanent employment. The 
flow out of unemployment has to equal the flow into unemployment as well as the flow into temporary jobs, so $\varphi \mathrm{u}=\lambda\left[\mathrm{e}_{\mathrm{T}} \mathrm{G}(\underline{\varepsilon})+\mathrm{e}_{\mathrm{P}} \mathrm{G}(\bar{\varepsilon})\right]=\lambda \mathrm{e}_{\mathrm{T}}$. Using the steady state conditions and the identity $\mathrm{u}+\mathrm{e}_{\mathrm{T}}+\mathrm{e}_{\mathrm{P}}=1$, yields the steady state values of unemployment, temporary employment and permanent employment,

$$
\begin{gathered}
\mathrm{u}=[\lambda \mathrm{G}(\bar{\varepsilon})] /[\lambda \mathrm{G}(\bar{\varepsilon})+\varphi(\mathrm{G}(\bar{\varepsilon})+\lambda(1-\mathrm{G}(\underline{\varepsilon})))], \\
\mathrm{e}_{\mathrm{T}}=[\varphi \mathrm{G}(\overline{\bar{\varepsilon}})] /[\lambda \mathrm{G}(\bar{\varepsilon})+\varphi(\mathrm{G}(\overline{\bar{\varepsilon}})+\lambda(1-\mathrm{G}(\underline{\varepsilon})))], \\
\mathrm{e}_{\mathrm{P}}=[\varphi(1-\mathrm{G}(\underline{\varepsilon}))] /[\lambda \mathrm{G}(\bar{\varepsilon})+\varphi(\mathrm{G}(\bar{\varepsilon})+\lambda(1-\mathrm{G}(\underline{\varepsilon})))] .
\end{gathered}
$$

For given $\varphi$, unemployment and temporary employment increase with $\underline{\varepsilon}$ and $\bar{\varepsilon}$, while permanent employment decreases with $\underline{\varepsilon}$ and $\bar{\varepsilon}$. Consequently, a reduction in dismissal costs has an ambiguous effect on permanent employment and a reduction in payroll taxes increases permanent employment if the link between benefits and contributions is not perfect.

As in Blanchard and Landier, which looks at the effect of reducing dismissal costs for temporary contracts, our theoretical discussion suggests the reduction in dismissal costs for permanent contracts increases hiring and dismissal and has ambiguous effects on unemployment. In contrast, while Blanchard and Landier find that reducing temporary dismissal costs reduces permanent conversions and increases the perm-temp wage differential, here a reduction in permanent dismissal costs increases permanent conversions and reduces the wage differential. Thus, unlike previous reforms affecting temporary contracts only, the 97 reform should reduce labor market segmentation.

\section{Identification Strategy}

Our goal in this paper is to identify the impact of reduced payroll taxes and dismissal costs on permanent contracts. To this end, we compare treated groups under 
30 and over 45 years of age with the control group of middle-aged workers before and after the 1997 reform. We concentrate on contrasts by age group since other treated groups - the long-term unemployed and women under-represented in certain occupations - may be self-selected. While self-selection is not as much of a concern for disabled workers, unfortunately our data does not allow us to distinguish disabled workers. Moreover, as shown in Figures 1 and 2 above, the greatest impact of the reform appears to have been on the two affected age groups.

The identification strategy is illustrated in Figures 3 and 4, which plot permanent employment probabilities for men and women by age group relative to the base period, first quarter of 1997, for the same years as Figures 1 and 2 (i.e., 1995-2000) ${ }^{6}$ The figures show that permanent employment probabilities started to increase after the implementation of the reform (i.e., second quarter of 1997) and that the increase was greatest for younger workers. Since the reform was introduced during an expansion, Figures 5 and 6 plot the permanent employment probabilities for men and women for the entire period for which we have data (i.e., 1987 to 2000), which spans another expansion in the late 1980's and a recession in the early 1990's. As before, these figures show the increase in permanent employment probabilities for the young after the second quarter of 1997, but they also show higher permanent employment probabilities for the young during the expansion of the late 1980's. The figures highlight the importance of proper control for cyclical effects, especially because the young appear to benefit disproportionately during expansions. On the other hand, the figures show similar permanent employment probabilities during the two expansions, even though the expansion of the late 1980's was stronger than the expansion of the late 1990's in terms of GDP growth. 
To control for age-specific cyclical effects, we use a triple differences estimator which compares the employment of treated and control individuals during the reform period with the employment of treated and control individuals during an earlier expansionary period. This triple differences estimator uses the period without reform to check for the possibility that expansions have differential effects on younger and older workers. ${ }^{\text {D }}$ In addition, the triple differences strategy is implemented in samples limited to narrower age groups, concentrated around the affected age groups. For example, the sample for the young is restricted to the 25-35 age group. Since the 25-30 age group and the 30-35 age group are likely to face similar age-specific cyclical effects, restricting the sample in this way is an important robustness check. In addition, limiting the sample to narrower age groups also allows to check whether workers not covered by the reform are being substituted for under 30 and over 45 year olds. If this were the case, then we should find much larger effects in the restricted samples.

The following logit model is used to implement the estimation strategy:

$$
\operatorname{Pr}\left[\mathrm{e}_{\mathrm{it}}=1 \mid \mathrm{X}_{\mathrm{it}}, \mathrm{d}_{\mathrm{i}}\right]=\Lambda\left[\alpha_{\mathrm{t}}+\beta^{\prime} \mathrm{d}_{\mathrm{i}}+\gamma^{\prime} \mathrm{X}_{\mathrm{it}}+\delta^{\prime}\left(\mathrm{d}_{\mathrm{i}} \times \mathrm{R}_{\mathrm{t}}\right)\right]
$$

where $e_{i t}=1$ if employed with a permanent contract and 0 otherwise; $d_{i}$ is a vector of dummies for treated groups, $\alpha_{t}$ is a year effect, and $X_{i t}$ includes covariates affecting individual $i$ at time $t$, including quarter dummies and, in some specifications, provinceand sector-specific trends. The group dummies capture differential permanent employment rates of the treated groups before and after the reform, while the quarter and year effects capture the impact of seasonal and macro shocks affecting workers in both treated and control groups. The province- and sector-specific trends control for

\footnotetext{
${ }^{6}$ These give the probabilities of being employed with permanent contracts relative to non-employment.

7 This strategy is in the spirit of the falsification test by Angrist and Krueger (1999) which uses the "Failed Mariel Boatlift" to examine the impact of immigration on the Miami labor market.
} 
factors affecting employment differentially in different provinces and sectors over time, including EU active labor market programs introduced in some Spanish regions and skilled-biased technical change. ${ }^{8} \mathrm{R}_{\mathrm{t}}$ is a dummy for reform years, so that $\delta$, the vector of reform/treatment group interactions, captures the effects of interest.

Specifications that control for age-specific cyclical effects include age group interactions with an expansion dummy, $\mathrm{E}_{\mathrm{t}}$, which equals 1 in 1987-90 and 1996-2000 and zero otherwise. That is, the estimating equation is modified to be

$$
\operatorname{Pr}\left[\mathrm{e}_{\mathrm{it}}=1 \mid \mathrm{X}_{\mathrm{it}}, \mathrm{di}\right]=\Lambda\left[\alpha_{\mathrm{t}}+\beta^{\prime} \mathrm{d}_{\mathrm{i}}+\gamma^{\prime} \mathrm{X}_{\mathrm{it}}+\delta_{\mathrm{E}}{ }^{\prime}\left(\mathrm{d}_{\mathrm{i}} \times \mathrm{E}_{\mathrm{t}}\right)+\delta_{\mathrm{R}}{ }^{\prime}\left(\mathrm{d}_{\mathrm{i}} \times \mathrm{E}_{\mathrm{t}} \times \mathrm{R}_{\mathrm{t}}\right)\right] .
$$

Here, the impact of the reform is captured by the third-order term, $\delta_{R}$, which measures the reform impact relative to the pre-treatment expansion. The age-specific cyclical effect is captured by the expansion interaction, $\delta_{\mathrm{E}}$.

Finally, transition probabilities from non-employment to permanent employment, from temporary employment to permanent employment, and from permanent employment to non-employment, were estimated by fitting equations (7) and (8) conditional on the relevant labor market state. That is, all parameters are free to vary with employment status in period $t-1$. As with the models for employment levels, some of the specifications for transitions control for age-specific cyclical effects by allowing differential transition probabilities for treated groups during the expansions of the late 1980's and 1990's.

\footnotetext{
${ }^{8}$ We include interactions of province and sector dummies with a time trend because both active labor market programs and technical change increased during the 1990's. However, in contrast to the sharp timing of the 1997 reform which was introduced after the second quarter of 1997, the timing of EU active labor market programs and especially skilled-biased technical change cannot be identified precisely. In addition, the inclusion of sector- and province-specific trends helps to control for the serial correlation problem in differences-in-differences inference pointed out by Bertrand, Duflo, and Mullainathan (2001).
} 


\section{Estimates of the Impact of the 1997 Reform}

\section{A. Data and Descriptive Statistics}

Our data comes from the Spanish Labor Force Survey (LFS) from the second quarter of 1987 to the fourth quarter of 2000. ${ }^{2}$ The LFS has information on basic individual and family information, including information about sex, age, province of residence, education, marital status, and whether the person is a household head or not. The LFS also includes labor force information including employment status, occupation, sector, tenure and type of contract in the current and previous jobs. 10 We exclude individuals in the military, workers employed in agriculture, as well as employers, coop members, family workers and the self-employed from our sample. Our samples include men and women between 16 and 65 years of age to focus on young and older workers affected by the reform.

The LFS has a rotating panel structure that follows individuals for a maximum of six quarters, replacing one-sixth of the sample every quarter. In practice, there is attrition and not everyone is followed for six quarters. Jiménez and Peracchi (2002) report an attrition rate of about $20 \%$ in the rotating panel, which is close to that found for similar data sets in other countries. records from one quarter to the next using the personal identification number of the

\footnotetext{
${ }^{9}$ The LFS underwent a number of methodological changes in 1995. Prior to 1995 the LFS sampled randomly out of the 1980 population Census, while after 1995 the LFS sampled randomly out of the 1991 population Census. Most importantly, prior to 1995, individuals between 25 and 45 years of age were under-sampled because of problems with the sampling framework which was corrected after 1995. These methodological changes have reduced the figures on aggregate unemployment estimated with the LFS, but as shown in Figures 2-6, they do not appear to have affected estimates of individual employment probabilities for those in particular age groups.

${ }^{10}$ The Spanish LFS does not have earnings information, so we cannot study the effect of payroll taxes and dismissal costs on wages. The presence of downward wage rigidities in the Spanish context, however, probably implies that most adjustments take place through quantities rather than through prices.

${ }^{11}$ Analysis on the more restrictive sample of workers between 21 and 59 years of age, who have stronger labor market attachment, shows similar results.

${ }^{12}$ Acemoglu and Angrist (2001) report an attrition rate of around 29\% in the CPS.
} 
individual. 13 We restrict ourselves to matches with the same sex in consecutive quarters.

The impact of the 1997 reform on employment levels is evaluated by looking at employment probabilities. The effects on worker flows are evaluated by looking at transition probabilities.

Table 2 presents descriptive statistics for men by age group for the periods before and after the reform. The table shows lower permanent employment probabilities for young men and women and middle-aged and older men after the reform, probably reflecting the fact that the pre-reform period includes the strong expansion of the late 1980 's. On the other hand, permanent employment probabilities are higher for middle-aged and older women after the reform. Simple comparisons of means also indicate lower transitions during the post-reform period. However, as shown in the regressions below, controlling for year effects and other covariates shows a different picture. Men and women are also older, more educated, less likely to be married, and have shorter tenures during the reform period. In contrast, men are less likely and women more likely to be the head of household during the reform period.

\section{B. Employment Effects}

Table 3 reports logit marginal effects estimated using equations (7) and (8). The dependent variable is a discrete variable which takes the value of 1 if the person is employed with a permanent contract and 0 if the person is non-employed (either unemployed or out of the labor force). The controls in these logits are head of household and marital status dummies, four schooling groups, tenure, seven occupation groups, 10 sector groups, 15 province main effects, year effects, quarter effects and under 30 and over 45 age groups. The effects of interest are captured by the interactions

\footnotetext{
${ }^{13}$ Including year and quarter effects helps us control for cohort effects.
} 
of the under 30 and over 45 age groups with the reform dummy. The marginal effects of these interactions capture the change in permanent employment probabilities of younger and older relative to middle-aged workers during the reform years. Panels A and B show the results for men and women, respectively. The results show a large and statistically significant increase in permanent employment probabilities for young relative to middle-aged workers after the 1997 reform became effective, but insignificant effects for older workers. The reported standard errors allow for clustering by year-age group to control for common random effects within these cells. 14 For example, Column (1) shows that the probability of permanent employment increased by 0.0222 for younger men and by 0.016 for young women relative to middle-aged workers during the reform years. Columns (2) and (3) report the results for specifications which control for sector- and province-specific trends. The results do not change.

Column (4) controls for age-specific cyclical effects by including interactions of the under 30 and over 45 age groups with an expansion dummy. The results show that while expansions do seem to disproportionately benefit younger workers, they do not benefit older relative to middle-aged workers. Moreover, controlling for the beneficial effects of expansions on younger workers, the results become smaller and remain significant when standard errors are not corrected for clustering but become insignificant after accounting for correlation of shocks within each year-age group cell. Nonetheless, since the expansion of the late 1980's was stronger in terms of GDP growth, our control for age-specific cyclical effects probably provides a lower bound of

\footnotetext{
${ }^{14}$ As is typical in data with a group structure like ours, adjusting for group clustering seems much more important than adjusting for the fact that the rotation group structure means that some individuals are followed through time (see, e.g., studies using the CPS). Since the two-way adjustment is complex, we
} 
the effect of the reform. The next two columns limit the sample to narrower age groups to further control for age-specific cyclical effects. Column (5) uses the 25-30 age group as the treated and the 30-35 age group as the control for young workers, while Column (6) uses the 45-55 age group as the treated and the 40-45 age group as the control for older workers. The results in Column (5) of Panel A show that permanent employment probabilities increase by 0.014 (i.e., $2.5 \%$ ) for young men relative to middle-aged men during the reform years. The results in Column (5) of Panel B show insignificant effects for young women. In addition, the effects of the reform on older workers remain insignificant after controlling for age-specific cyclical effects.

\section{Effects on Worker Flows}

Table 4 reports logit marginal effects from models for transitions from nonemployment to permanent employment. The dependent variable is a discrete variable which takes the value of 1 if the person transited from non-employment to permanent employment from one quarter to the next and 0 if the person continues to be nonemployed the next quarter. ${ }^{15}$ As before, Panel A reports the results for men and Panel B for women. The results show increased transitions from non-employment to permanent employment for young relative to middle-aged workers after the 1997 reform became effective. For example, Column (1) in Panel A shows an increase in the relative transition probabilities from non-employment to permanent employment of 0.045 or $45 \%$ for younger men during the reform years. Column (1) in Panel B also shows an increase in the relative probability of transiting from non-employment to permanent employment of 0.01 or $16 \%$ (with a p-value of 0.187 ) for younger women during the

report standard errors correcting only for the former. The latter increases standard errors by only about a third, with little effect on significance levels, while group-clustering more than triples the standard errors.

${ }^{15}$ The controls are as in the permanent employment probability specifications. 
reform years. Controlling for sector- and province-specific trends in Columns (2) and (3) does not change the results. The results for older workers are insignificant.

The rest of the columns in Table 4 report results which control for age-specific cyclical effects. Column (4) in Panel A shows a smaller effect on the probability of transiting from non-employment to permanent employment for young men during the expansion of the late 1980's, but a larger and now significant effect for older men. The transition from non-employment to permanent employment falls to 0.037 or $37 \%$ for younger men, but increases to 0.05 or $20 \%$ for older men. Results on the restricted sample of younger men in Column (5) now show no significant effect of the reform on transitions from non-employment to permanent employment. On the contrary, results on the restricted sample of older men in Column (6) now show a large and significant effect of 0.052 or $21 \%$ of the reform on the transitions from non-employment to permanent employment. The results for women in Panel B continue to show increased transitions from non-employment to employment of between $13 \%$ and $16 \%$ (with pvalues of 0.17 ) for the full and restricted samples. The results for older women are insignificant.

Table 5 reports logit marginal effects from models for transitions from temporary to permanent employment. $\frac{16}{16}$ The results in Panel A show a statistically significant increase in the transitions from temporary to permanent employment for younger relative to middle-aged men during the reform years. The results without controlling for age-specific cyclical effects suggest an increase of about 0.03 or $36 \%$, while the results which control for age-specific cyclical effects indicate an increase of between 0.024 and 0.028 (or between $29 \%$ and $33 \%$ ). On the contrary, the results show no significant change in the transitions from temporary to permanent employment 
for older men. The results in Panel B also show a significant increase in temporary to permanent transition probabilities for young women but not for older women. The results without controlling for age-specific cyclical effects suggest an increase of about 0.0225 or $26 \%$, while the results which control for age-specific cyclical effects indicate an increase of between 0.01 and 0.02 (or between $13 \%$ and $23 \%$ ).

Table 6 reports logit marginal effects from models for transitions from

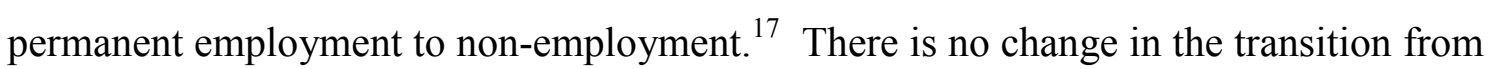
permanent employment to non-employment for young workers during the reform years, which explains why increased flows from non-employment and temporary to permanent employment suggested by Tables 4 and 5 translate into a net positive effect on permanent employment. On the contrary, Panel A in Table 6 shows a rise in the transition from permanent employment to non-employment for older relative to middleaged men during the reform years of between $7.5 \%$ and $8.8 \%$, with and without controlling for age-specific cyclical effects. The results become smaller and insignificant when we restrict the treated group of older workers to those under 55. In the case of older men, the increased flows from non-employment to permanent employment shown in Table 4 and the increased flows from permanent employment to non-employment shown in this table appear to cancel out, explaining the weak net effect on permanent employment. On the other hand, the effects for older women are insignificant as was the case with the other flows.

\section{Economic Interpretation of Magnitudes}

Estimates of the net effect on young men and women in Table 3 can be compared to the effect of the 1997 reform on the costs of employing young men to

\footnotetext{
${ }^{16}$ The controls are as in the permanent employment probability specifications.
} 
estimate elasticities of permanent employment with respect to non-wage labor costs. We concentrate on young workers because the results for older workers and young women show insignificant effects after controlling for age-specific cyclical effects, suggesting no response to the reform by this group of workers.

The 1997 reform reduced dismissal costs from 45 to 33 days per year worked or, equivalently, a reduction of $26.7 \%$. In addition, the reform reduced the uniform payroll tax rate of $28.3 \%$ of the salary of young workers by $40 \%$ for contracts signed in 1997 and 1998 during the first two years of the contract, and by $35 \%$ and $25 \%$ for contracts signed after 1999 during the first and second years of the contract, respectively. To estimate the percent change in total costs implied by the reform, we need to multiply the changes in dismissal costs and payroll taxes by the fraction of expected dismissal costs and payroll taxes in total labor costs. Expected quarterly costs for unfair dismissals are equal to the probability of an unfair dismissal times the estimated costs of unfair dismissals. While we do not have the probability of a dismissal, Table 2 reports separation rates by age (i.e., 3.3\% for young men). The probability of ruling a dismissal unfair in Spain is $0.72 \frac{18}{18}$ Costs for unfair dismissals can be estimated based on the following formula:

Dismissal Costs $=(45 / 365) \times$ Yearly Salary $\times$ Tenure in Years.

Mean salaries from the Survey of Salary Structure for 1995 indicate a yearly salary of 3,830 Euros for young men. ${ }^{19}$ From the LFS we get mean tenures for young

\footnotetext{
${ }^{17}$ The controls are as in the permanent employment probability specifications.

${ }^{18}$ Galdón-Sánchez and Güell (2000).

${ }^{19}$ Average salaries are low because they include very young workers many of whom still live at home in Spain.
} 
men of 2.16 years in 1995 . Combining these numbers, we get quarterly expected dismissal cost of 24.23 Euros for young men. 20

Payroll tax costs are easier to obtain. The payroll tax rate is $28.3 \%$, implying a quarterly payroll tax cost of 271 Euros for young men. Consequently, dismissal costs and payroll taxes account for about $1.9 \%$ and $21.6 \%$ of total labor costs for young men, respectively. Multiplying these figures by the corresponding percent changes in dismissal costs and payroll taxes gives the percent change in total labor costs as a result of the reform. Using the larger payroll tax reductions of $40 \%$ for young workers, the percent reductions in total labor costs implied by the reform for young men was of $9.2 \%$. Using the smaller payroll tax reductions of $30 \%$ for young workers applied during the second year of the contract, the percent reductions in total labor costs implied by the reform for young men was of $7 \%$. Of the total labor cost reduction for young men induced by the reform, $92.7 \%$ and $94.4 \%$ can be attributed to the larger payroll tax reduction and to the smaller payroll tax reduction, respectively. This means that while payroll tax reductions were smaller in absolute terms for younger than for older workers, the payroll tax reductions were relatively more important for younger workers.

Results in Table 3 that control for age-specific cyclical effects suggest the reform increased permanent employment probabilities by 0.0144 or $2.5 \%$ for young men. These results imply elasticities of between -0.27 and -0.36 for young men using payroll tax reductions of $40 \%$ and $30 \%$, respectively. The results suggest a moderately elastic employment response of young men to changes in non-wage labor costs, but an

\footnotetext{
${ }^{20}$ This means we do no have to consider the change in the maximum payment of dismissal costs from 42 to 24 months, since it is never binding.
} 
inelastic response of older workers and young women. 22 This is probably because of the relative importance of payroll tax reductions for young workers, which suggests a positive net employment effect when the benefit-contribution linkage is not perfect. On the other hand, the inelastic response for young women suggests that other considerations besides non-labor costs are more important for firms in terms of hiring women.

\section{Conclusion}

Natural experiments that can be used to assess the consequences of employment contract regulations in Europe are rare. This paper uses the Spanish labor market reform of 1997, which reduced payroll taxes and dismissal costs, to set up a research design based on the fact that the reform applied differently to different age groups. Our theoretical framework suggests the reduction in dismissal costs should increase conversions and dismissals, with an ambiguous effect on employment. On the other hand, the reduction in payroll taxes should increase conversions and, thus, permanent employment. Estimates using the Spanish Labor Force Survey suggest that the reform increased permanent employment probabilities for young relative to middle-aged workers. The results for young men are robust to controls for common macro shocks for all age groups, for sector- and province-specific trends, and for age-specific cyclical effects. The results also show increases in the relative transitions from non-employment to permanent employment for young and older men, although the results for older men are not always significant, and from temporary to permanent employment for young

\footnotetext{
${ }^{21}$ Although payroll tax reductions for older workers ranged between $50 \%$ and $60 \%$, they only accounted for between $47 \%$ and $51 \%$ of the total reduction in non-wage labor costs because of the relatively high dismissal costs for this group of workers.

${ }^{22}$ Katz (1998) and Nickell and Bell (1996) discuss the possibility that high labor costs increase unemployment rates for disadvantaged workers, including youth.
} 
men and women during the reform period. On the other hand, relative transitions from permanent employment to non-employment increase only for older men.

Our results suggest that the reduction in dismissal costs and payroll taxes increased both hiring and dismissals for older men, but had a positive effect on the hiring margin of young workers with little effect on dismissals. This explains why the reform seems to have had a positive net effect on permanent employment for young workers but not for older workers. This is probably because of the relative importance of payroll tax reductions for young workers, which suggests positive effects on hiring and net employment when the benefit-contribution linkage is not perfect.

The estimated elasticities suggest a moderately elastic response of permanent employment to non-wage labor costs for younger men for whom the payroll tax reduction was relatively more important. Further institutional reform along the lines of the 1997 legislation seems at least as likely to increase employment levels as reforms promoting the use of temporary contracts. On balance, the results reported here support the view, widely discussed though not previously substantiated, that the high non-wage labor costs and lack of flexibility associated with permanent contracts have reduced employment levels in Spain, especially for young workers. 


\section{References}

Abowd, John, Francis Kramarz, and David Margolis. 1999. "Minimum Wages and Employment in France and the United States," CEPR Working Paper No. 2159.

Acemoglu, Daron, and Joshua Angrist. 2001. "Consequences of Employment Protection? The Case of the Americans with Disabilities Act," Journal of Political Economy, 109(5): 915-957.

Angrist, Joshua, and Adriana Kugler. 2003. "Protective or Counter-Productive? Labor Market Institutions and the Effect of Immigration on EU Natives," forthcoming Economic Journal.

Angrist, Joshua, and Alan Krueger. 1999. "Empirical Strategies in Labor Economics," in Orley Ashenfelter and David Card, eds., Handbook of Labor Economics, Vol.3A, pp.1277-1366. Amsterdam: Elsevier Science, North-Holland.

Bentolila, Samuel, and Juan J. Dolado. 1994. "Labour Flexibility and Wages: Lessons from Spain,” Economic Policy, 9(18): 53-99.

Bentolila, Samuel and Gilles Saint-Paul. 1992. "The Macroeconomic Impact of Flexible Labour Contracts, with an Application to Spain," European Economic Review, 36(5): 1013-1047.

Bertola, Giusseppe, and Andrea Ichino. 1995. "Crossing the River: a Comparative Perspective on Italian Employment Dynamics,” Economic Policy, 0: 359-415.

Bertrand, Marianne, Esther Duflo and Sendhil Mullainthan. 2001. "How Much Should We Trust Differences-in-Differences Estimates?," MIT Department of Economics Working Paper No. 01/34.

Blanchard, Olivier, and Augustin Landier. 2002. "The Perverse Effects of Partial Labor Market Reform: Fixed Duration contracts in France,” Economic Journal, 112.

Bover, Olympia, Manuel Arellano, and Samuel Bentolila. 2002. "Unemployment Duration, Benefit Duration and the Business Cycle," Economic Journal, 112(479): 22365.

Bover, Olympia and Ramon Gómez. 1999. "Another Look at Unemployment Duration: Long-term Unemployment and Exit to a Permanent Job," Bank of Spain Working Paper No.9903.

Blundell, Richard, Monica Costa Dias, and Costas Meghir. 2001. "Evaluating the Employment Impact of a Mandatory Job Search Assistance Program," IFS Working paper $01 / 20$.

Cahuc, Pierre and François Postel-Vinay. 2002. "Temporary Jobs, Employment Protection and Labour Market Performance", Labour Economics, 9(1): 63-92. 
Dolado, Juan J., Carlos García-Serrano, and Juan F. Jimeno. 2002. "Drawing Lessons from the Boom of Temporary Jobs in Spain,” Economic Journal, 112(480): F270-295.

Dolado, Juan J., Marcel Jansen, and Juan F. Jimeno. 2002. "A Matching Model of Crowing-Out and On-the-Job Search (with an Application to Spain)," FEDEA, Working Paper No. 2002-12.

Donald, Stephen and Kevin Lang. 2001. "Inference with Difference in Differences and Other Panel Data,” Boston University, mimeo.

Fougére, Denis, Francis Kramarz, and Thierry Magnac. 2000. "Youth Employment Policies in France," European Economic Review, 44(4-6): 928-942.

Galdón-Sánchez, José E. and Maia Güell. 2000. "Let's Go to Court! Firing Costs and Dismissal Conflicts," Princeton University Working Paper No. 444.

Garcia-Fontes, Walter, and Hugo Hopenhayn. 1996. "Creación y Destrucción de Empleo en la Economía Española," in Ramon Marimon, ed. La Economía Española: una Vissión Diferente. Barcelona: Antoni Bosch Editor.

Garcia-Pérez, Ignacio, and Fernando Muñoz-Bullón. 2002. "The Nineties in Spain: too much Flexibility in the Labor Market?," mimeo.

Güell-Rottlan, Maia and Barbara Petrongolo. 2000. "Workers' Transitions from Temporary to Permanent Employment: The Spanish Case," CEP Discussion Paper No. 438.

Hamermesh, Daniel. 1993. Labor Demand. Princeton, N.J.: Princeton University Press.

Jiménez, Sergi, and Franco Peracchi. 2002. "Sample Attrition and Labor Force Dynamics: Evidence from the Spanish Labor Force Surveys," Spanish Economic Review, 4: 79-102.

Jimeno, Juan F., and Luis Toharia. 1996. "Effort, Absenteeism, and Fixed Term Employment Contracts," Revista Española de Economía, 13(1): 105-119.

Jimeno, Juan F. And Luis Toharia. 1993. "The Effects of Fixed-Term Employment on Wages: Theory and Evidence from Spain," Investigaciones Económicas, 17(3): 475494.

Katz, Lawrence. 1998. "Wage Subsidies for the Disadvantaged," in Richard Freeman and Peter Gottschalk, eds., Generating Jobs, pp. 21-53. New York: Russell Sage Foundation.

Kramarz, Francis, and Thomas Philippon. 2000. "The Impact of Differential Payroll Tax Subsidies on Minimum Wage Employment," mimeo. 
Kugler, Adriana, and Gilles Saint-Paul. 2003. "How do Firing Costs Affect Worker Flows in a World with Adverse Selection?," forthcoming Journal of Labor Economics.

Kugler, Adriana.1999. The Impact of Firing Costs on Turnover and Unemployment: Evidence from the Colombian Labour Market Reform," International Tax and Public Finance, 6(3): 389-410.

Laroque, Guy and Bernard Salanie. 2002. "Labour Market Institutions and Employment in France," Journal of Applied Econometrics, 7(1): 25-48.

Nickell, Stephen and Richard Layard. 1999. "Labor Market Institutions and Economic Performance," in David Card and Orley Ashenfelter, eds., Handbook of Labor Economics, Vol. 3C, pp. 3029-2084.

Nickell, Stephen. 1997. "Unemployment and Labor Market Rigidities: Europe versus North America," Journal of Economic Perspectives, 11: 55-74.

Nickell, Stephen, and Brian Bell. 1996. "Would Cutting Taxes on the Unskilled have a Significant Impact on Unemployment?," in Dennis Snower and Guillermo de la Dehesa, eds. Unemployment Policy: Government Options for the Labour Market, pp.296-328. Cambridge: Cambridge University Press.

Oyer, Paul, and Scott Schaeffer. 2000. "Layoffs and Litigation," RAND Journal of Economics, 31(2): 345-58.

Phelps, Edmund. 1996. "Wage Subsidy Programs: Alternative Designs," in Dennis Snower and Guillermo de la Dehesa, eds. Unemployment Policy: Government Options for the Labour Market, pp. 206-243. Cambridge: Cambridge University Press.

Phelps, Edmund. 1994. "Low-Wage Employment Subsidies versus the Welfare State," American Economic Review, 84: 54-58.

Saint-Paul, Gilles. 1996. "Exploring the Political Economy of Labour Market Institutions," Economic Policy, 265-315.

Sanz, M.C. 1994. "Una Estimación de la Demanda de Trabajo Manual y no Manual," Investigaciones Económicas, 18(2): 333-364.

Snower, Dennis. 1994. "Converting Unemployment Benefits into Wage Subsidies," American Economic Review, 84: 65-70. 
Table 1: Labor Market Reforms after 1997:

Reductions in Payroll Taxes and Dismissal Costs for Permanent Contracts

\begin{tabular}{|c|c|c|c|c|}
\hline & $\begin{array}{l}\text { Dismissal costs under existing } \\
\text { permanent contracts }\end{array}$ & $\begin{array}{l}\text { Dismissal costs under new } \\
\text { permanent contracts }\end{array}$ & $\begin{array}{l}\text { Payroll tax reductions for } \\
\text { newly hired workers under } \\
\text { permanent contracts in 1997- } \\
1998\end{array}$ & $\begin{array}{l}\text { Payroll tax reductions for } \\
\text { newly hired workers under } \\
\text { permanent contracts in } 1999\end{array}$ \\
\hline $\begin{array}{l}\text { Unemployed aged } 30-44 \\
\text { years }\end{array}$ & $\begin{array}{l}\text { Fair dismissals: } 20 \text { days' wages } \\
\text { per year of seniority with a } \\
\text { maximum of } 12 \text { months' wages } \\
\text { Unfair dismissals: } 45 \text { days' } \\
\text { wages per year of seniority with } \\
\text { a maximum of } 42 \text { months' wages }\end{array}$ & $\begin{array}{l}\text { Fair dismissals: } 20 \text { days' wages } \\
\text { per year of seniority with a } \\
\text { maximum of } 12 \text { months' wages } \\
\text { Unfair dismissals: } 45 \text { days' } \\
\text { wages per year of seniority with } \\
\text { a maximum of } 42 \text { months' wages }\end{array}$ & None & None \\
\hline $\begin{array}{l}\text { Young unemployed } \\
\text { workers (under } 30 \\
\text { years of age) }\end{array}$ & $\begin{array}{l}\text { Fair dismissals: } 20 \text { days' wages } \\
\text { per year of seniority with a } \\
\text { maximum of } 12 \text { months' wages } \\
\text { Unfair dismissals: } 45 \text { days' } \\
\text { wages per year of seniority with } \\
\text { a maximum of } 42 \text { months' wages }\end{array}$ & $\begin{array}{l}\text { Fair dismissals: } 20 \text { days' wages } \\
\text { per year of seniority with a } \\
\text { maximum of } 12 \text { months' wages } \\
\text { Unfair dismissals: } 33 \text { days' } \\
\text { wages per year of seniority with } \\
\text { a maximum of } 24 \text { months' wages }\end{array}$ & $\begin{array}{l}40 \% \text { of employer contributions } \\
\text { for } 24 \text { months }\end{array}$ & $\begin{array}{l}35 \% \text { of employer contributions } \\
\text { for } 12 \text { months, } 25 \% \text { for another } \\
12 \text { months }\end{array}$ \\
\hline $\begin{array}{l}\text { Unemployed workers } \\
\text { above } 45 \text { years of age }\end{array}$ & $\begin{array}{l}\text { Fair dismissals: } 20 \text { days' wages } \\
\text { per year of seniority with a } \\
\text { maximum of } 12 \text { months' wages } \\
\text { Unfair dismissals: } 45 \text { days' } \\
\text { wages per year of seniority with } \\
\text { a maximum of } 42 \text { months' wages }\end{array}$ & $\begin{array}{l}\text { Fair dismissals: } 20 \text { days' wages } \\
\text { per year of seniority with a } \\
\text { maximum of } 12 \text { months' wages } \\
\text { Unfair dismissals: } 33 \text { days' } \\
\text { wages per year of seniority with } \\
\text { a maximum of } 24 \text { months' wages }\end{array}$ & $\begin{array}{l}60 \% \text { of employer contributions } \\
\text { for } 24 \text { months, } 50 \% \text { thereafter }\end{array}$ & $\begin{array}{l}45 \% \text { of employer contributions } \\
\text { for } 12 \text { months, } 40 \% \text { for another } \\
12 \text { months }\end{array}$ \\
\hline $\begin{array}{l}\text { Long-term unemployed } \\
\text { (over } 1 \text { year of } \\
\text { registered } \\
\text { unemployment) }\end{array}$ & $\begin{array}{l}\text { Fair dismissals: } 20 \text { days' wages } \\
\text { per year of seniority with a } \\
\text { maximum of } 12 \text { months' wages } \\
\text { Unfair dismissals: } 45 \text { days' } \\
\text { wages per year of seniority with } \\
\text { a maximum of } 42 \text { months' wages }\end{array}$ & $\begin{array}{l}\text { Fair dismissals: } 20 \text { days' wages } \\
\text { per year of seniority with a } \\
\text { maximum of } 12 \text { months' wages } \\
\text { Unfair dismissals: } 33 \text { days' } \\
\text { wages per year of seniority with } \\
\text { a maximum of } 24 \text { months' wages }\end{array}$ & $\begin{array}{l}40 \% \text { of employer contributions } \\
\text { for } 24 \text { months }\end{array}$ & $\begin{array}{l}40 \% \text { of employer contributions } \\
\text { for } 12 \text { months, } 30 \% \text { for another } \\
12 \text { months }\end{array}$ \\
\hline $\begin{array}{l}\text { Workers employed } \\
\text { under temporary } \\
\text { contracts }\end{array}$ & $\begin{array}{l}\text { Fair dismissals: } 20 \text { days' wages } \\
\text { per year of seniority with a } \\
\text { maximum of } 12 \text { months' wages } \\
\text { Unfair dismissals: } 45 \text { days' } \\
\text { wages per year of seniority with } \\
\text { a maximum of } 42 \text { months' wages }\end{array}$ & $\begin{array}{l}\text { Fair dismissals: } 20 \text { days' wages } \\
\text { per year of seniority with a } \\
\text { maximum of } 12 \text { months' wages } \\
\text { Unfair dismissals: } 33 \text { days' } \\
\text { wages per year of seniority with } \\
\text { a maximum of } 24 \text { months' wages }\end{array}$ & $\begin{array}{l}50 \% \text { employer contributions for } \\
24 \text { months, } 20 \% \text { for another } 12 \\
\text { months }\end{array}$ & None \\
\hline $\begin{array}{l}\text { Women hired under } \\
\text { temporary contracts or } \\
\text { long-term unemployed } \\
\text { hired in occupations } \\
\text { with low weight of } \\
\text { female employment }\end{array}$ & $\begin{array}{l}\text { Fair dismissals: } 20 \text { days' wages } \\
\text { per year of seniority with a } \\
\text { maximum of } 12 \text { months' wages } \\
\text { Unfair dismissals: } 45 \text { days' } \\
\text { wages per year of seniority with } \\
\text { a maximum of } 42 \text { months' wages }\end{array}$ & $\begin{array}{l}\text { Fair dismissals: } 20 \text { days' wages } \\
\text { per year of seniority with a } \\
\text { maximum of } 12 \text { months' wages } \\
\text { Unfair dismissals: } 33 \text { days' } \\
\text { wages per year of seniority with } \\
\text { a maximum of } 24 \text { months' wages }\end{array}$ & $\begin{array}{l}60 \% \text { employer contributions for } \\
24 \text { months, } 20 \% \text { for another } 12 \\
\text { months }\end{array}$ & $\begin{array}{l}45 \% \text { employer contributions for } \\
24 \text { months, } 40 \% \text { for another } 12 \\
\text { months }\end{array}$ \\
\hline $\begin{array}{l}\text { Workers hires under } \\
\text { training contracts }\end{array}$ & $\begin{array}{l}\text { Fair dismissals: } 20 \text { days' wages } \\
\text { per year of seniority with a } \\
\text { maximum of } 12 \text { months' wages } \\
\text { Unfair dismissals: } 45 \text { days' } \\
\text { wages per year of seniority with } \\
\text { a maximum of } 42 \text { months' wages }\end{array}$ & $\begin{array}{l}\text { Fair dismissals: } 20 \text { days' wages } \\
\text { per year of seniority with a } \\
\text { maximum of } 12 \text { months' wages } \\
\text { Unfair dismissals: } 33 \text { days' } \\
\text { wages per year of seniority with } \\
\text { a maximum of } 24 \text { months' wages }\end{array}$ & $\begin{array}{l}50 \% \text { employer contributions for } \\
24 \text { months, } 20 \% \text { for another } 12 \\
\text { months }\end{array}$ & $\begin{array}{l}25 \% \text { employer contributions for } \\
24 \text { months }\end{array}$ \\
\hline $\begin{array}{l}\text { Workers above } 45 \text { years } \\
\text { of age hired under } \\
\text { temporary contracts }\end{array}$ & $\begin{array}{l}\text { Fair dismissals: } 20 \text { days' wages } \\
\text { per year of seniority with a } \\
\text { maximum of } 12 \text { months' wages } \\
\text { Unfair dismissals: } 45 \text { days' } \\
\text { wages per year of seniority with } \\
\text { a maximum of } 42 \text { months' wages }\end{array}$ & $\begin{array}{l}\text { Fair dismissals: } 20 \text { days' wages } \\
\text { per year of seniority with a } \\
\text { maximum of } 12 \text { months' wages } \\
\text { Unfair dismissals: } 33 \text { days' } \\
\text { wages per year of seniority with } \\
\text { a maximum of } 24 \text { months' wages }\end{array}$ & $\begin{array}{l}60 \% \text { employer contributions for } \\
24 \text { months, } 20 \% \text { for another } 12 \\
\text { months }\end{array}$ & $\begin{array}{l}60 \% \text { employer contributions for } \\
24 \text { months, } 20 \% \text { for another } 12 \\
\text { months }\end{array}$ \\
\hline Disabled workers & $\begin{array}{l}\text { Fair dismissals: } 20 \text { days' wages } \\
\text { per year of seniority with a } \\
\text { maximum of } 12 \text { months' wages } \\
\text { Unfair dismissals: } 45 \text { days' } \\
\text { wages per year of seniority with } \\
\text { a maximum of } 42 \text { months' wages }\end{array}$ & $\begin{array}{l}\text { Fair dismissals: } 20 \text { days' wages } \\
\text { per year of seniority with a } \\
\text { maximum of } 12 \text { months' wages } \\
\text { Unfair dismissals: } 33 \text { days' } \\
\text { wages per year of seniority with } \\
\text { a maximum of } 24 \text { months' wages }\end{array}$ & $\begin{array}{l}70 \%-90 \% \text { for the whole } \\
\text { employment spell }\end{array}$ & $\begin{array}{l}70 \%-90 \% \text { for the whole } \\
\text { employment spell }\end{array}$ \\
\hline
\end{tabular}


Table 2: Descriptive Statistics by Age Group, Before and After the 1997 Reform

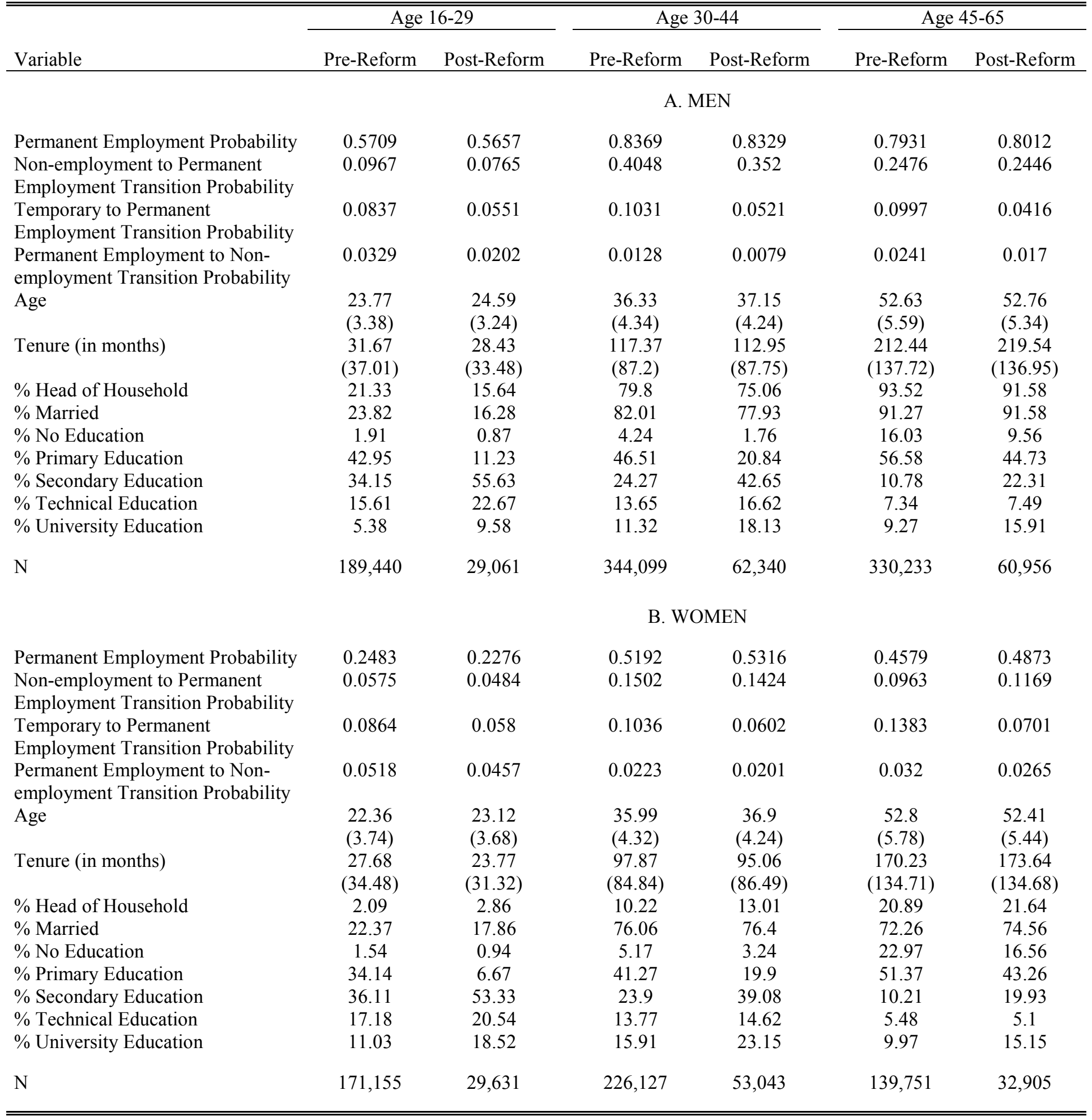

Notes: The table reports means, probabilities, and percentages for the indicated age group. Standard deviations are in parentheses where appropriate. 
Table 3: Permanent Employment Probabilities

\begin{tabular}{|c|c|c|c|c|c|c|}
\hline \multirow[b]{2}{*}{ Regressors } & \multicolumn{4}{|c|}{ Full Sample } & \multicolumn{2}{|c|}{ Restricted Age Groups } \\
\hline & (1) & (2) & (3) & (4) & (5) & (6) \\
\hline & \multicolumn{6}{|c|}{ A. MEN } \\
\hline Age $<30$ & $\begin{array}{c}-0.0404 * \\
(0.0159)\end{array}$ & $\begin{array}{c}-0.0404 * \\
(0.0159)\end{array}$ & $\begin{array}{c}-0.0404 * \\
(0.0159)\end{array}$ & $\begin{array}{c}-0.0515^{*} \\
(0.0163)\end{array}$ & $\begin{array}{c}0.0432 * \\
(0.0034)\end{array}$ & - \\
\hline Age $>=45$ & $\begin{array}{c}-1.0105^{*} \\
(0.027)\end{array}$ & $\begin{array}{c}-1.0105^{*} \\
(0.027)\end{array}$ & $\begin{array}{c}-1.0105 * \\
(0.0105)\end{array}$ & $\begin{array}{c}-1.0016^{*} \\
(0.0243)\end{array}$ & - & $\begin{array}{c}-0.0741 \\
(0.0043)\end{array}$ \\
\hline Age $<30 \times$ Reform & $\begin{array}{c}0.0222 * * \\
(0.0101)\end{array}$ & $\begin{array}{c}0.0222 * * \\
(0.0101)\end{array}$ & $\begin{array}{c}0.0222 * * \\
(0.0101)\end{array}$ & $\begin{array}{c}0.0151 \\
(0.0118)\end{array}$ & $\begin{array}{c}0.0144^{+} \\
(0.0091)\end{array}$ & - \\
\hline Age $>=45 \times$ Reform & $\begin{array}{c}0.0043 \\
(0.0143)\end{array}$ & $\begin{array}{c}0.0043 \\
(0.0143)\end{array}$ & $\begin{array}{c}0.0043 \\
(0.0143)\end{array}$ & $\begin{array}{c}0.0097 \\
(0.016)\end{array}$ & - & $\begin{array}{c}0.0081 \\
(0.0078)\end{array}$ \\
\hline Age $<30 \times$ Expansion & - & - & - & $\begin{array}{l}0.0184 * \\
(0.0166)\end{array}$ & $\begin{array}{c}0.0001 \\
(0.0029)\end{array}$ & - \\
\hline Age $>=45 \times$ Expansion & - & - & - & $\begin{array}{c}0.0137 \\
(0.0235)\end{array}$ & - & $\begin{array}{r}-0.0082 \\
(0.008)\end{array}$ \\
\hline Log-likelihood & $-283,995$ & $-283,997$ & $-283,994$ & $-283,950$ & $-71,957$ & $-82,050$ \\
\hline \multirow[t]{2}{*}{$\mathrm{N}$} & 711,989 & 711,989 & 711,989 & 711,989 & 193,182 & 282,292 \\
\hline & \multicolumn{6}{|c|}{ B. WOMEN } \\
\hline Age $<30$ & $\begin{array}{c}-0.0501 * \\
(0.0124)\end{array}$ & $\begin{array}{c}-0.0502 * \\
(0.0124)\end{array}$ & $\begin{array}{c}-0.0501 * \\
(0.0124)\end{array}$ & $\begin{array}{l}-0.069 * \\
(0.0117)\end{array}$ & $\begin{array}{c}0.0068 \\
(0.0075)\end{array}$ & - \\
\hline Age $>=45$ & $\begin{array}{c}-0.0321^{+} \\
(0.0194)\end{array}$ & $\begin{array}{c}-0.0321^{+} \\
(0.0194)\end{array}$ & $\begin{array}{l}-0.0321^{+} \\
(0.0194)\end{array}$ & $\begin{array}{c}-0.0184 \\
(0.0176)\end{array}$ & - & $\begin{array}{c}-0.0064 \\
(0.0066)\end{array}$ \\
\hline Age $<30 \times$ Reform & $\begin{array}{l}0.016^{+} \\
(0.01)\end{array}$ & $\begin{array}{c}0.0161^{+} \\
(0.01)\end{array}$ & $\begin{array}{l}0.016^{+} \\
(0.01)\end{array}$ & $\begin{array}{c}0.0057 \\
(0.0121)\end{array}$ & $\begin{array}{c}0.0155 \\
(0.0117)\end{array}$ & - \\
\hline Age $>=45 \times$ Reform & $\begin{array}{c}-0.004 \\
(0.0141)\end{array}$ & $\begin{array}{c}-0.004 \\
(0.0141)\end{array}$ & $\begin{array}{c}0.004 \\
(0.0141)\end{array}$ & $\begin{array}{c}0.0036 \\
(0.0173)\end{array}$ & - & $\begin{array}{c}0.0122 \\
(0.0091)\end{array}$ \\
\hline Age $<30 \times$ Expansion & - & - & - & $\begin{array}{c}0.0303 * * \\
(0.0157)\end{array}$ & $\begin{array}{c}0.0088 \\
(0.0085)\end{array}$ & - \\
\hline Age $>=45 \times$ Expansion & - & - & - & $\begin{array}{c}0.0199 \\
(0.0271)\end{array}$ & - & $\begin{array}{c}-0.0021 \\
(0.0104)\end{array}$ \\
\hline Log-likelihood & $-221,097$ & $-221,099$ & $-221,096$ & $-221,055$ & $-82,834$ & $-54,735$ \\
\hline $\mathrm{N}$ & 465,739 & 465,739 & 465,739 & 465,739 & 166,295 & 142,534 \\
\hline Sector Trends & NO & YES & NO & NO & NO & NO \\
\hline Province Trends & NO & NO & YES & YES & YES & YES \\
\hline
\end{tabular}

Note: The table reports logit marginal effects. The robust standard errors reported in parenthesis allow for clustering by year/age group. The logit controls for age and year main effects, quarter effects, head of household and marital status dummies, education, tenure, and occupation, sector, and province dummies. The first four columns use the entire sample, while the last two columns restrict the sample to age groups which allow for more comparable treatment and control groups. The sample in Column (5) is restricted to the 25-35 age group and the sample in Column (6) is restricted to the $40-55$ age group. * Significant at $1 \%$ level, ** Significant at $5 \%$ level, ${ }^{+}$Significant at $10 \%$ level. 

Table 4: Transition Probabilities from Non-employment to Permanent Employment

\begin{tabular}{|c|c|c|c|c|c|c|}
\hline \multirow[b]{2}{*}{ Regressors } & \multicolumn{4}{|c|}{ Full Sample } & \multicolumn{2}{|c|}{ Restricted Age Groups } \\
\hline & $(1)$ & (2) & (3) & (4) & $(5)$ & (6) \\
\hline & \multicolumn{6}{|c|}{ A. MEN } \\
\hline Age $<30$ & $\begin{array}{c}-0.0034 \\
(0.0133)\end{array}$ & $\begin{array}{c}-0.0034 \\
(0.0133)\end{array}$ & $\begin{array}{c}-0.0034 \\
(0.0133)\end{array}$ & $\begin{array}{c}-0.0053 \\
(0.0135)\end{array}$ & $\begin{array}{c}0.0139 \\
(0.0134)\end{array}$ & - \\
\hline Age $>=45$ & $\begin{array}{c}-0.1208 * \\
(0.0212)\end{array}$ & $\begin{array}{c}-0.1208 * \\
(0.0212)\end{array}$ & $\begin{array}{c}-0.1208 * \\
(0.0212)\end{array}$ & $\begin{array}{c}-0.0657 * \\
(0.0182)\end{array}$ & - & $\begin{array}{c}0.0116 \\
(0.0135)\end{array}$ \\
\hline Age $<30$ x Reform & $\begin{array}{c}0.0447 * \\
(0.015)\end{array}$ & $\begin{array}{l}0.0446^{*} \\
(0.0149)\end{array}$ & $\begin{array}{c}0.0447^{*} \\
(0.015)\end{array}$ & $\begin{array}{l}0.0365^{*} \\
(0.0142)\end{array}$ & $\begin{array}{c}0.017 \\
(0.0159)\end{array}$ & - \\
\hline Age $>=45 \times$ Reform & $\begin{array}{c}0.0209 \\
(0.0218)\end{array}$ & $\begin{array}{c}0.0209 \\
(0.0218)\end{array}$ & $\begin{array}{c}0.0209 \\
(0.0218)\end{array}$ & $\begin{array}{c}0.0496^{* *} \\
(0.0251)\end{array}$ & - & $\begin{array}{c}0.0519^{*} \\
(0.0184)\end{array}$ \\
\hline Age $<30 \times$ Expansion & - & - & - & $\begin{array}{c}0.0052 \\
(0.0176)\end{array}$ & $\begin{array}{c}-0.009 \\
(0.0134)\end{array}$ & - \\
\hline Age $>=45 \times$ Expansion & - & - & - & $\begin{array}{c}-0.0866^{*} \\
(0.034)\end{array}$ & - & $\begin{array}{c}-0.0812 \\
(0.0259)\end{array}$ \\
\hline Log-likelihood & $-13,310$ & $-13,310$ & $-13,310$ & $-13,295$ & $-4,376$ & $-3,522$ \\
\hline \multirow[t]{2}{*}{$\mathrm{N}$} & 138,039 & 138,039 & 138,039 & 138,039 & 38,928 & 34,898 \\
\hline & \multicolumn{6}{|c|}{ B. WOMEN } \\
\hline Age $<30$ & $\begin{array}{c}-0.0221 * \\
(0.0046)\end{array}$ & $\begin{array}{c}-0.0221 * \\
(0.0046)\end{array}$ & $\begin{array}{c}-0.0221 * \\
(0.0046)\end{array}$ & $\begin{array}{c}-0.0162 * \\
(0.0034)\end{array}$ & $\begin{array}{c}-0.0131 * \\
(0.0034)\end{array}$ & - \\
\hline Age $>=45$ & $\begin{array}{c}0.008 \\
(0.0074)\end{array}$ & $\begin{array}{c}0.008 \\
(0.0074)\end{array}$ & $\begin{array}{c}0.008 \\
(0.0074)\end{array}$ & $\begin{array}{l}0.0315^{*} \\
(0.0034)\end{array}$ & - & $\begin{array}{c}0.0174 * \\
(0.0022)\end{array}$ \\
\hline Age $<30 \times$ Reform & $\begin{array}{c}0.0095 \\
(0.0072)\end{array}$ & $\begin{array}{c}0.0095 \\
(0.0072)\end{array}$ & $\begin{array}{c}0.0096 \\
(0.0072)\end{array}$ & $\begin{array}{c}0.0097 \\
(0.0071)\end{array}$ & $\begin{array}{c}0.0077 \\
(0.0057)\end{array}$ & - \\
\hline Age $>=45 \times$ Reform & $\begin{array}{l}-0.0061 \\
(0.0083)\end{array}$ & $\begin{array}{c}0.0061 \\
(0.0083)\end{array}$ & $\begin{array}{c}0.0061 \\
(0.0083)\end{array}$ & $\begin{array}{c}0.0029 \\
(0.0084)\end{array}$ & - & $\begin{array}{c}-0.0001 \\
(0.0092)\end{array}$ \\
\hline Age $<30 \times$ Expansion & - & - & - & $\begin{array}{c}-0.0077 \\
(0.0054)\end{array}$ & $\begin{array}{c}0.0019 \\
(0.0064)\end{array}$ & - \\
\hline Age $>=45 \times$ Expansion & - & - & - & $\begin{array}{c}-0.0339 * \\
(0.0098)\end{array}$ & - & $\begin{array}{c}-0.0197^{*} \\
(0.0076)\end{array}$ \\
\hline Log-likelihood & $-15,143$ & $-15,143$ & $-15,143$ & $-15,137$ & $-5,452$ & $-3,885$ \\
\hline $\mathrm{N}$ & 153,541 & 153,541 & 153,541 & 153,541 & 61,246 & 33,682 \\
\hline Sector Trends & NO & YES & NO & NO & NO & NO \\
\hline Province Trends & NO & NO & YES & YES & YES & YES \\
\hline
\end{tabular}

Note: The table reports logit marginal effects. The robust standard errors reported in parenthesis allow for clustering by year/age group. The logit controls for age and year main effects, quarter effects, head of household and marital status dummies, education, tenure, and occupation, sector, and province dummies. The first four columns use the entire sample, while the last two columns restrict the sample to age groups which allow for more comparable treatment and control groups. The sample in Column (5) is restricted to the 25-35 age group and the sample in Column (6) is restricted to the $40-55$ age group. * Significant at $1 \%$ level, ** Significant at 5\% level, ${ }^{+}$Significant at $10 \%$ level. 
Table 5: Transition Probabilities from Temporary to Permanent Employment

\begin{tabular}{|c|c|c|c|c|c|c|}
\hline \multirow[b]{2}{*}{ Regressors } & \multicolumn{4}{|c|}{ Full Sample } & \multicolumn{2}{|c|}{ Restricted Age Groups } \\
\hline & (1) & (2) & (3) & (4) & (5) & (6) \\
\hline & \multicolumn{6}{|c|}{ A. MEN } \\
\hline Age $<30$ & $\begin{array}{c}-0.0174 * \\
(0.0067)\end{array}$ & $\begin{array}{c}-0.0195 * \\
(0.0029)\end{array}$ & $\begin{array}{c}-0.0195 * \\
(0.0029)\end{array}$ & $\begin{array}{c}-0.0235^{*} \\
(0.0029)\end{array}$ & $\begin{array}{c}-0.0088^{* *} \\
(0.0039)\end{array}$ & - \\
\hline Age $>=45$ & $\begin{array}{c}0.0029 \\
(0.0061)\end{array}$ & $\begin{array}{c}-0.0018 \\
(0.0018)\end{array}$ & $\begin{array}{c}-0.0018 \\
(0.0018)\end{array}$ & $\begin{array}{c}-0.0037 * * \\
(0.0019)\end{array}$ & - & $\begin{array}{c}-0.0069 \\
(0.0017)\end{array}$ \\
\hline Age $<30 \times$ Reform & $\begin{array}{l}0.0295^{*} \\
(0.0077)\end{array}$ & $\begin{array}{l}0.0307 * \\
(0.0048)\end{array}$ & $\begin{array}{c}0.0307^{*} \\
(0.0048)\end{array}$ & $\begin{array}{l}0.0282^{*} \\
(0.0049)\end{array}$ & $\begin{array}{l}0.0237^{*} \\
(0.0041)\end{array}$ & - \\
\hline Age $>=45 \times$ Reform & $\begin{array}{c}-0.0139^{+} \\
(0.0084)\end{array}$ & $\begin{array}{c}-0.0123^{+} \\
(0.0067)\end{array}$ & $\begin{array}{c}-0.0123^{+} \\
(0.0067)\end{array}$ & $\begin{array}{c}-0.0133^{+} \\
(0.0069)\end{array}$ & - & $\begin{array}{c}-0.0054 \\
(0.0048)\end{array}$ \\
\hline Age $<30 \times$ Expansion & - & - & - & $\begin{array}{c}0.0067 * * \\
(0.0029)\end{array}$ & $\begin{array}{c}-0.0033 \\
(0.0041)\end{array}$ & - \\
\hline Age $>=45 \times$ Expansion & - & - & - & $\begin{array}{c}0.0031 \\
(0.0026)\end{array}$ & - & $\begin{array}{c}0.0117^{*} \\
(0.0036)\end{array}$ \\
\hline Log-likelihood & $-39,643$ & $-39,448$ & $-39,449$ & $-39,447$ & $-17,335$ & $-7,478$ \\
\hline \multirow[t]{2}{*}{$\mathrm{N}$} & 176,337 & 176,337 & 176,337 & 176,337 & 70,219 & 35,238 \\
\hline & \multicolumn{6}{|c|}{ B. WOMEN } \\
\hline Age $<30$ & $\begin{array}{c}-0.0203 * \\
(0.0029)\end{array}$ & $\begin{array}{c}-0.0203 * \\
(0.0028)\end{array}$ & $\begin{array}{c}-0.0203 * \\
(0.0029)\end{array}$ & $\begin{array}{c}-0.0306^{*} \\
(0.0017)\end{array}$ & $\begin{array}{c}0.0237^{*} \\
(0.002)\end{array}$ & - \\
\hline Age $>=45$ & $\begin{array}{l}0.0229 * \\
(0.0033)\end{array}$ & $\begin{array}{c}0.0229 * \\
(0.0033)\end{array}$ & $\begin{array}{c}0.0229 * \\
(0.0033)\end{array}$ & $\begin{array}{l}0.0207 * \\
(0.0024)\end{array}$ & - & $\begin{array}{c}0.0166 \\
(0.0025)\end{array}$ \\
\hline Age $<30 \times$ Reform & $\begin{array}{l}0.0226^{*} \\
(0.0072)\end{array}$ & $\begin{array}{l}0.0225^{*} \\
(0.0071)\end{array}$ & $\begin{array}{l}0.0226^{*} \\
(0.0072)\end{array}$ & $\begin{array}{l}0.0201 * \\
(0.0069)\end{array}$ & $\begin{array}{l}0.0111^{+} \\
(0.007)\end{array}$ & - \\
\hline Age $>=45 \times$ Reform & $\begin{array}{l}-0.0105 \\
(0.0074)\end{array}$ & $\begin{array}{c}-0.0105 \\
(0.0074)\end{array}$ & $\begin{array}{c}-0.0105 \\
(0.0074)\end{array}$ & $\begin{array}{l}-0.0103 \\
(0.0076)\end{array}$ & - & $\begin{array}{l}-0.0017 \\
(0.0032)\end{array}$ \\
\hline Age $<30 \times$ Expansion & - & - & - & $\begin{array}{l}0.0136^{*} \\
(0.0024)\end{array}$ & $\begin{array}{c}0.0154 \\
(0.0027)\end{array}$ & - \\
\hline Age $>=45 \times$ Expansion & - & - & - & $\begin{array}{c}0.0032 \\
(0.0047)\end{array}$ & - & $\begin{array}{c}0.0045 \\
(0.0043)\end{array}$ \\
\hline Log-likelihood & $-44,833$ & $-44,833$ & -44833 & $-44,828$ & $-17,705$ & $-8,245$ \\
\hline $\mathrm{N}$ & 153,471 & 153,471 & 153,471 & 153,471 & 58,918 & 25,097 \\
\hline Sector Trends & NO & YES & NO & NO & NO & NO \\
\hline Province Trends & NO & NO & YES & YES & YES & YES \\
\hline
\end{tabular}

Note: The table reports logit marginal effects. The robust standard errors reported in parenthesis allow for clustering by year/age group. The logit controls for age and year main effects, quarter effects, head of household and marital status dummies, and education. The first four columns use the entire sample, while the last two columns restrict the sample to age groups which allow for more comparable treatment and control groups. The sample in Column (3) is restricted to the 25-35 age group and the sample in Column (4) is restricted to the $40-55$ age group. * Significant at $1 \%$ level. 
Table 6: Transition Probabilities from Permanent Employment to Non-employment

\begin{tabular}{|c|c|c|c|c|c|c|}
\hline \multirow[b]{2}{*}{ Regressors } & \multicolumn{4}{|c|}{ Full Sample } & \multicolumn{2}{|c|}{ Restricted Age Groups } \\
\hline & (1) & (2) & (3) & (4) & (5) & (6) \\
\hline & \multicolumn{6}{|c|}{ A. MEN } \\
\hline Age $<30$ & $\begin{array}{l}0.0098^{*} \\
(0.0015)\end{array}$ & $\begin{array}{l}0.0098^{*} \\
(0.0015)\end{array}$ & $\begin{array}{c}0.0098 * \\
(0.0016)\end{array}$ & $\begin{array}{l}0.0098 * \\
(0.0017)\end{array}$ & $\begin{array}{l}-0.0012 \\
(0.0009)\end{array}$ & - \\
\hline Age $>=45$ & $\begin{array}{c}0.0124^{*} \\
(0.0011)\end{array}$ & $\begin{array}{l}0.0124^{*} \\
(0.0011)\end{array}$ & $\begin{array}{l}0.0124^{*} \\
(0.0011)\end{array}$ & $\begin{array}{l}0.0127 * \\
(0.0011)\end{array}$ & - & $\begin{array}{c}0.0055 \\
(0.0007)\end{array}$ \\
\hline Age $<30 \times$ Reform & $\begin{array}{c}0.0002 \\
(0.0009)\end{array}$ & $\begin{array}{c}0.0002 \\
(0.0009)\end{array}$ & $\begin{array}{c}0.0002 \\
(0.0009)\end{array}$ & $\begin{array}{c}0.0002 \\
(0.0011)\end{array}$ & $\begin{array}{c}0.002 \\
(0.0017)\end{array}$ & - \\
\hline Age $>=45 \times$ Reform & $\begin{array}{c}0.0018^{* *} \\
(0.0009)\end{array}$ & $\begin{array}{c}0.0018^{* *} \\
(0.0009)\end{array}$ & $\begin{array}{c}0.0018^{* *} \\
(0.0009)\end{array}$ & $\begin{array}{c}0.0021 * * \\
(0.0012)\end{array}$ & - & $\begin{array}{c}0.0008 \\
(0.0009)\end{array}$ \\
\hline Age $<30 \times$ Expansion & - & - & - & $\begin{array}{c}0.0 \\
(0.0012)\end{array}$ & $\begin{array}{c}0.0004 \\
(0.0018)\end{array}$ & - \\
\hline Age $>=45 \times$ Expansion & - & - & - & $\begin{array}{c}0.0006 \\
(0.0008)\end{array}$ & - & $\begin{array}{c}0.0008 \\
(0.0009)\end{array}$ \\
\hline Log-likelihood & $-39,064$ & $-39,064$ & $-39,064$ & $-39,063$ & $-8,690$ & $-12,840$ \\
\hline \multirow[t]{2}{*}{$\mathrm{N}$} & 475,228 & 475,228 & 475,228 & 475,228 & 124,727 & 220,715 \\
\hline & \multicolumn{6}{|c|}{ B. WOMEN } \\
\hline Age $<30$ & $\begin{array}{c}0.0276^{* *} \\
(0.0012)\end{array}$ & $\begin{array}{c}0,0276^{* *} \\
(0.0012)\end{array}$ & $\begin{array}{c}0,0276^{* *} \\
(0.0012)\end{array}$ & $\begin{array}{c}0.0311^{* *} \\
0.0011\end{array}$ & $\begin{array}{c}0.0172 \\
0.0007^{*}\end{array}$ & - \\
\hline Age $>=45$ & $\begin{array}{c}0.0026^{+} \\
(0.0012)\end{array}$ & $\begin{array}{c}0.0026^{+} \\
(0.0012)\end{array}$ & $\begin{array}{c}0.0026^{+} \\
(0.0012)\end{array}$ & $\begin{array}{c}0.0032^{* *} \\
0.001\end{array}$ & - & $\begin{array}{l}-0.002 \\
0.0005\end{array}$ \\
\hline Age $<30 \times$ Reform & $\begin{array}{c}0.0029 \\
(0.0027)\end{array}$ & $\begin{array}{c}0.0029 \\
(0.0027)\end{array}$ & $\begin{array}{c}0.0029 \\
(0.0027)\end{array}$ & $\begin{array}{c}0.004 \\
0.0028\end{array}$ & $\begin{array}{l}0.0003 \\
0.0016\end{array}$ & - \\
\hline Age $>=45 \times$ Reform & $\begin{array}{c}-0.002 \\
(0.0017)\end{array}$ & $\begin{array}{c}-0.002 \\
(0.0017)\end{array}$ & $\begin{array}{c}-0.002 \\
(0.0018)\end{array}$ & $\begin{array}{c}-0.002 \\
(0.0019)\end{array}$ & - & $\begin{array}{l}0.0018 \\
0.0022\end{array}$ \\
\hline Age $<30 \times$ Expansion & - & - & - & $\begin{array}{c}-0.0047 \\
(0.0015)\end{array}$ & $\begin{array}{c}-0.0029 * * \\
0.0014\end{array}$ & - \\
\hline Age $>=45 \times$ Expansion & - & - & - & $\begin{array}{c}-0.0008 \\
(0.0016)\end{array}$ & - & $\begin{array}{c}-0.0017^{+} \\
0.001\end{array}$ \\
\hline Log-likelihood & $-43,159$ & $-43,159$ & $-43,159$ & $-43,155$ & $-14,677$ & $-11,769$ \\
\hline $\mathrm{N}$ & 331,559 & 331,559 & 331,559 & 331,559 & 117,550 & 122,170 \\
\hline Sector Trends & NO & YES & NO & NO & NO & NO \\
\hline Province Trends & NO & NO & YES & YES & YES & YES \\
\hline
\end{tabular}

Note: The table reports logit marginal effects. The robust standard errors reported in parenthesis allow for clustering by year/age group. The logit controls for age and year main effects, quarter effects, head of household and marital status dummies, and education. The first four columns use the entire sample, while the last two columns restrict the sample to age groups which allow for more comparable treatment and control groups. The sample in Column (3) is restricted to the 25-35 age group and the sample in Column (4) is restricted to the $40-55$ age group. * Significant at $1 \%$ level, $* *$ Significant at $5 \%$ level. 
Figure 1: Number of New Permanent Contracts for Men

in Population Groups affected by the 1997 Reform

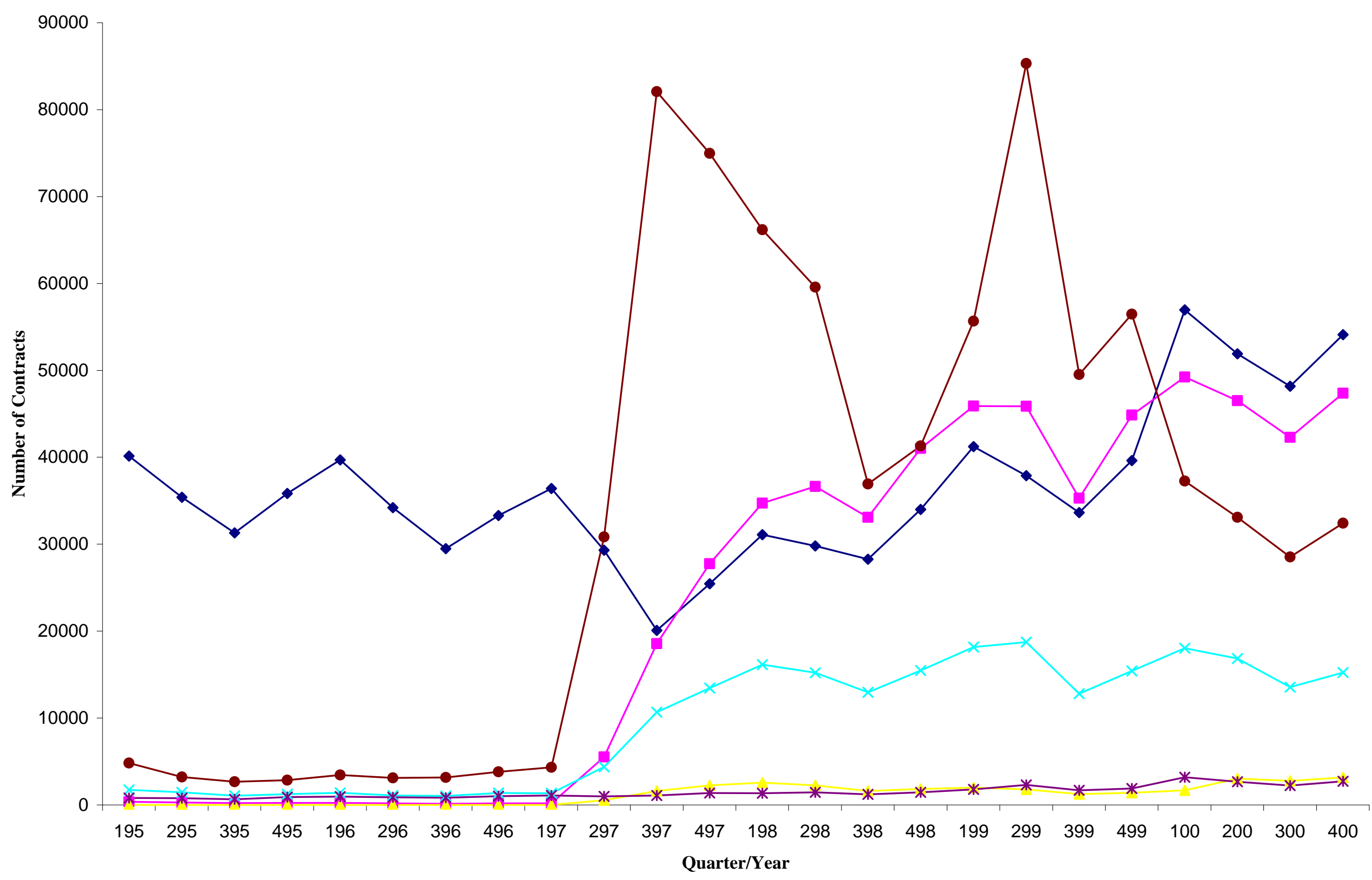


Figure 2: Number of New Permanent Contracts for Women

in Population Groups affected by the 1997 Reform

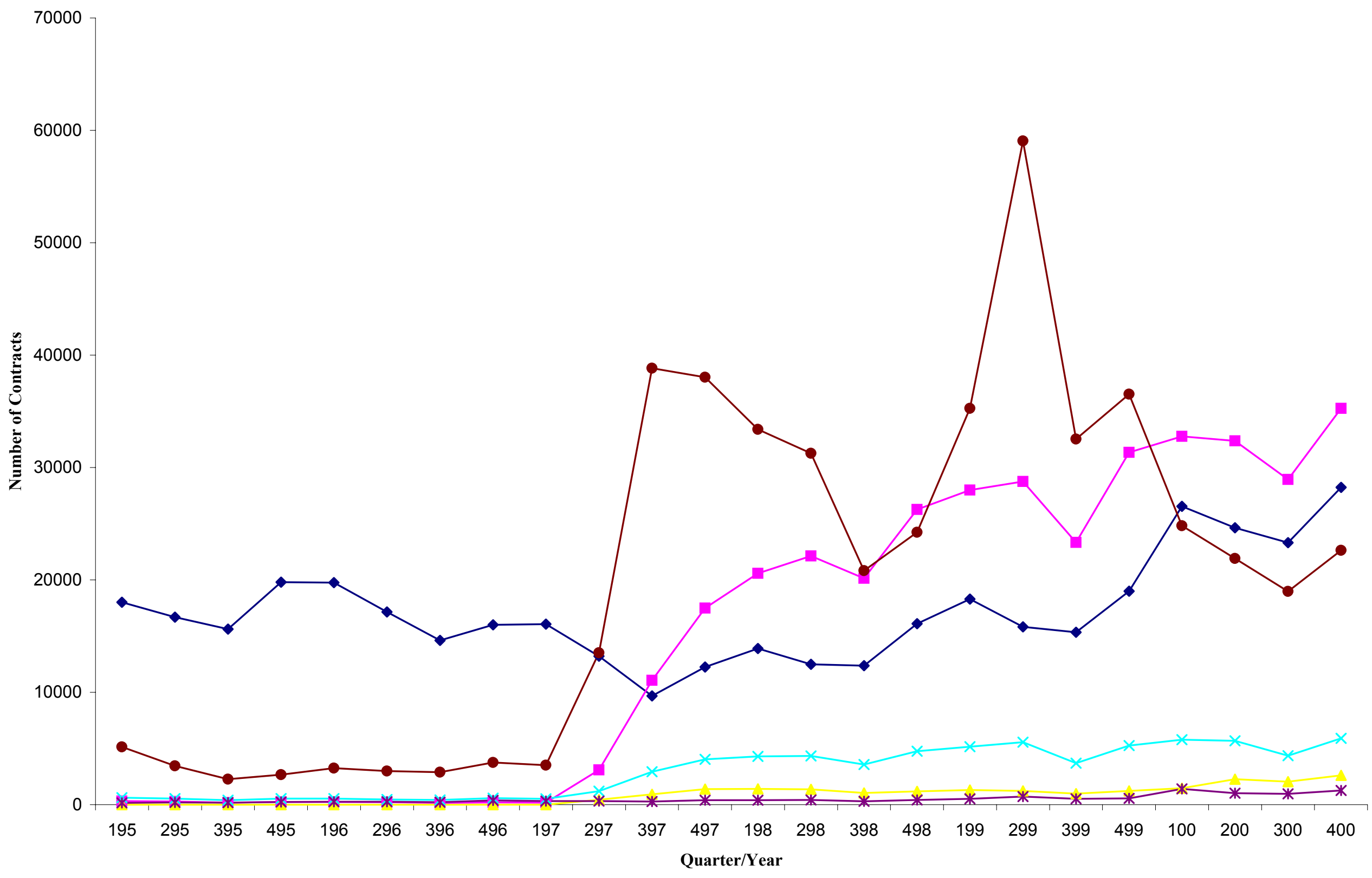


Figure 3: Permanent Employment Probabilities for Men by Age Group

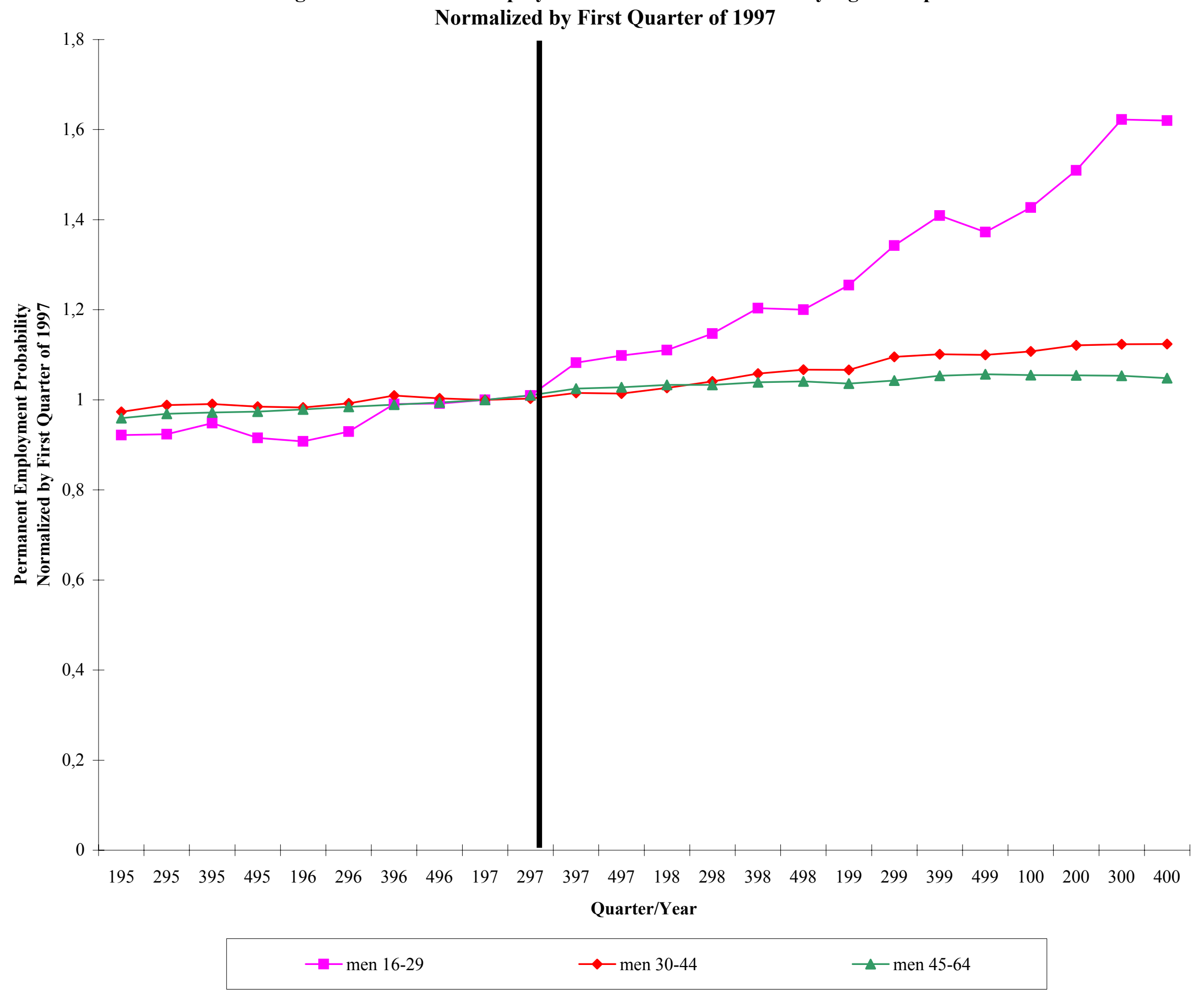


Figure 4: Permanent Employment Probabilities for Women by Age Group Normalized by First Quarter of 1997

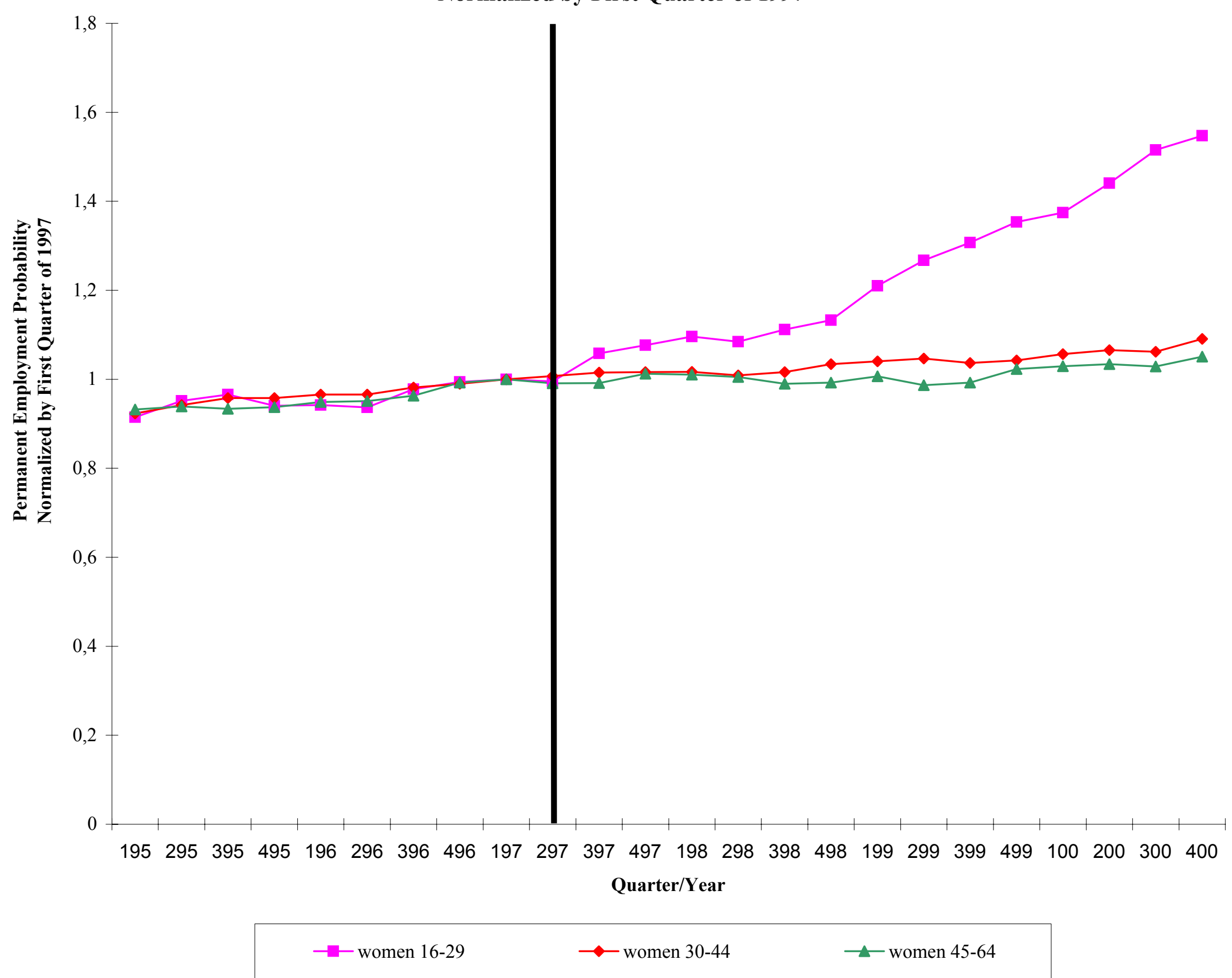


Figure 5: Permanent Employment Probabilities for Men by Age Group

Normalized by First Quarter of 1997

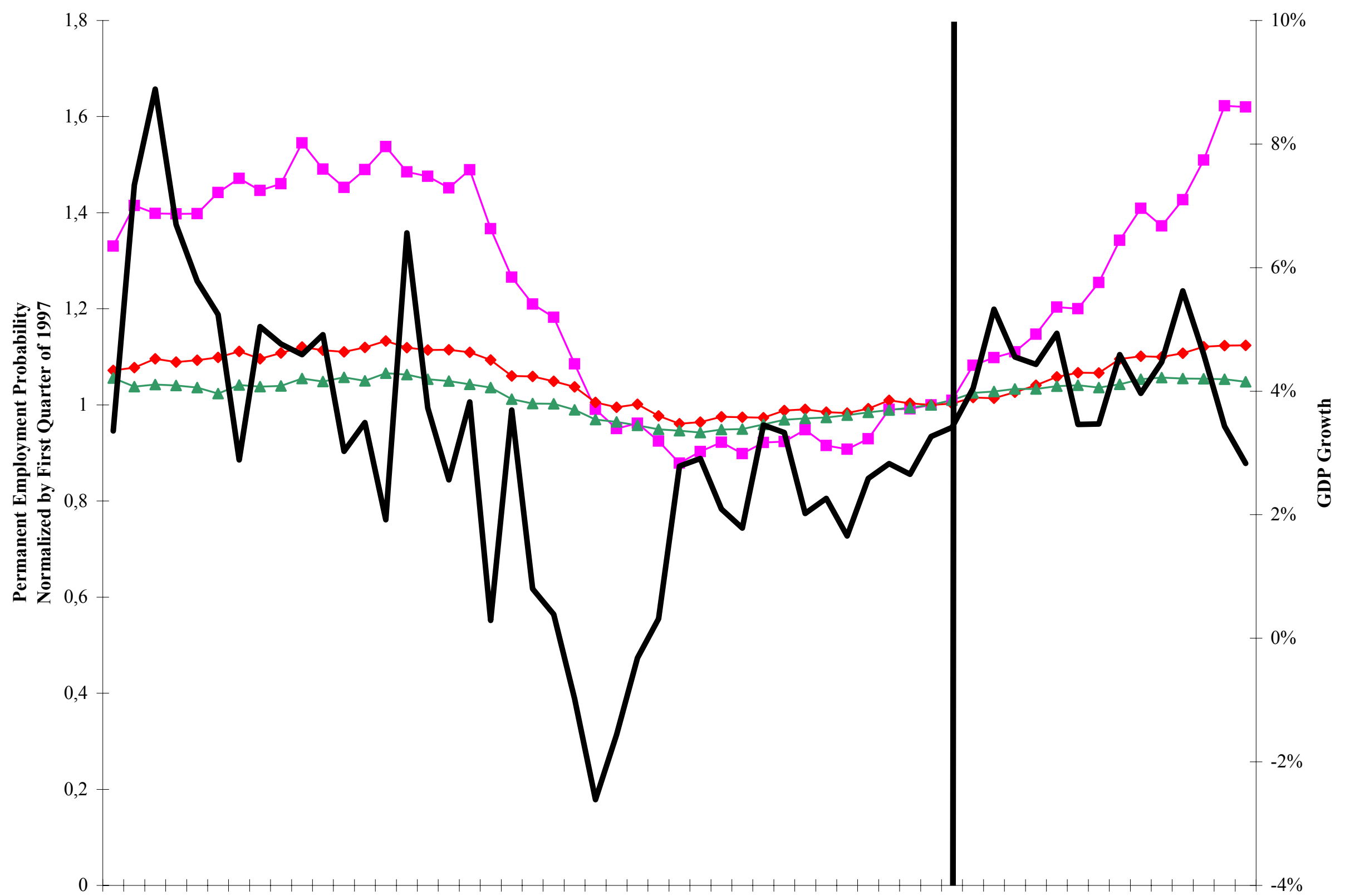

$\begin{array}{llllllllllllllllllllllllllll}287 & 487 & 288 & 488 & 289 & 489 & 290 & 490 & 291 & 491 & 292 & 492 & 293 & 493 & 294 & 494 & 295 & 495 & 296 & 496 & 297 & 497 & 298 & 498 & 299 & 499 & 200 & 400\end{array}$ Quarter/Year

$\neg-$ men 16-29 $\rightarrow$ men 30-44 $\rightarrow$ men 45-64 GDP Growth


Figure 6: Permanent Employment Probabilities for Women by Age Group Normalized by First Quarter 1997

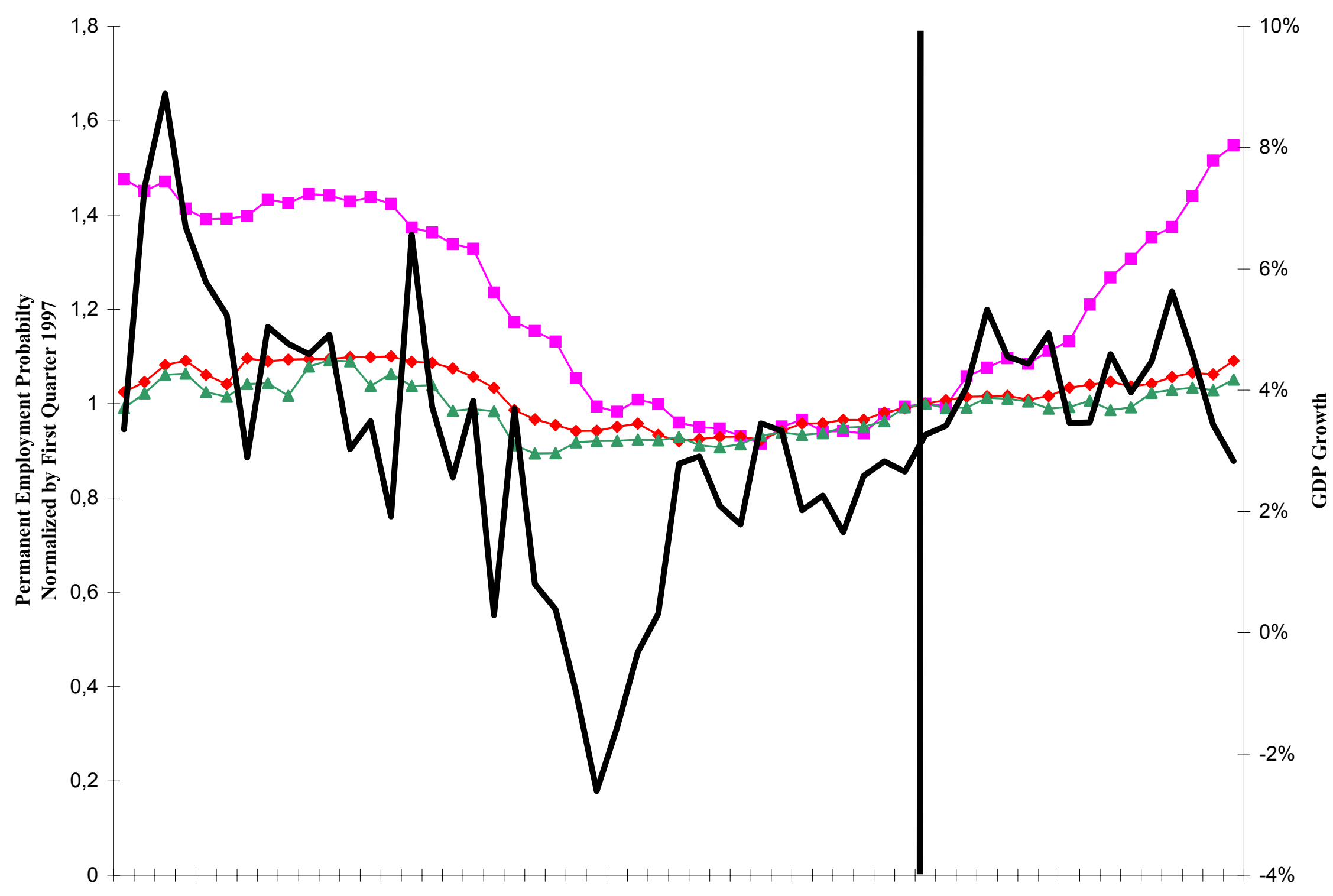

287487288488289489290490291491292492293493294494295495296496297497298498299499200400

Quarter/Year 